OECDpublishing

HOW ISLAMIC FINANCE CONTRIBUTES TO ACHIEVING THE SUSTAINABLE DEVELOPMENT GOALS

OECD DEVELOPMENT POLICY PAPERS June 2020 No. 30 



\section{OECD Policy Paper}

This paper is published under the responsibility of the Secretary-General of the OECD. The opinions expressed and arguments employed do not necessarily represent the official views of the OECD member countries.

This document, as well as any data and any map include herein, are without prejudice to the status of or sovereignty over any territory, to the delimitation of international frontiers and boundaries and to the name of any territory, city or area. The document was authorised for publication by Jorge Moreira da Silva, Director of the Development Cooperation Directorate.

Please cite this paper as OECD 2020, "How Islamic Finance Can Help Achieve the Sustainable Development Goals" OECD Development Co-operation Policy Papers, 30 OECD Publishing, Paris. 


\section{Abstract}

This report identifies the opportunities that Islamic finance presents for donors, as they look to deliver the Sustainable Development Goals (SDGs). To achieve the SDGs by 2030, Arab and OECD DAC donors need to mobilise innovative forms of financing and deliver the UN Secretary-General's call to deepen the transformation of development finance systems. DAC members could do so by, amongst other things, broadening and deepening exposure to alternative forms of financing, such as Islamic finance. Islamic finance represents USD 2.5 trillion - a share of which could potentially be mobilised for development - and its tenets resonate strongly across the member countries of the Organisation for Islamic Cooperation (57 members, many of which are developing countries) and beyond (e.g. with Muslims in DAC member countries). Arab donors could consider harnessing Islamic finance, as a means, to strengthen partnerships with DAC members, whilst increasing the effectiveness of existing aid flows in countries and contexts where they have considerable access. Doing so could create a more equitable and stable development finance order capable of delivering the SDGs and achieve greater impact in partner countries. Both communities would then be able to chart a path for all development actors, notably the private sector, development finance institutions and other bilateral donors to harness Islamic finance for development. This report provides a set of action points for Arab and DAC donors, highlighting the benefits of engaging in and co-operating through Islamic finance to deliver the SDGs. 


\section{Acknowledgments}

This report was prepared by the OECD Development Co-operation Directorate (DCD), under the guidance of Director Jorge Moreira da Silva.

The report was developed by Usman Nizami with Juan Casado-Asensio and benefited from the guidance of Ana Fernandes, Head of the Foresight, Outreach and Policy Reform Unit.

Fundamental contributions were provided by Blake Goud of the Responsible Finance and Investment (RFI) Foundation, Dr. Karim Allaoui of the Islamic Development Bank (IsDB), Andrew Stalbaum of the United Kingdom's (UK) Department for International Development, Safa El-Naser of the Deutsche Gesellschaft für Internationale Zusammenarbeit (GIZ), Niklaus Eggenberger of the Swiss Agency for Development and Cooperation, Ramya Gopalan of the International Federation of Red Cross and Red Crescent Societies (IFRC), Omar Shaikh of the UK's Islamic Finance Council, Arshadur Rahman of the Bank of England, Iqbal Nasim of the National Zakat Foundation, Aamir Rehman of United Nations Development Programme (UNDP) and from OECD colleagues (Irene Basile, Marisa Berbegal-Ibáñez, Stacey Bradbury, Sara Casadevall Bellés, Guillaume Delalande, Cyprien Fabre, Tomas Hos, Rachel Morris and Néstor Pelechà Aigües). 
6

\section{Table of Contents}

OECD Working Paper 3

$\begin{array}{ll}\text { Abstract } & 4\end{array}$

Acknowledgments $\quad 5$

$\begin{array}{ll}\text { Abbreviations and acronyms } & 7\end{array}$

Executive summary $\quad 8$

Awareness raising $\quad 8$

Transparency 9

New Arab-DAC partnerships on Islamic finance $\quad 9$

1. The contribution of Islamic finance to sustainable development 10

Islamic finance to deliver the Sustainable Development Goals 10

Islamic finance is complex and only some instruments can be used for development 13

2. Islamic social finance 18

Islamic social philanthropy and charitable giving $\quad 18$

Zakat $\quad 19$

Awqaf $\quad 25$

$\begin{array}{ll}\text { Way forward } & 27\end{array}$

3. Islamic financing and microfinancing 29

Sukuk 29

Islamic microfinance $\quad 34$

Way forward 36

4. Conclusions 38

Zakat 38

Awqaf $\quad 39$

$\begin{array}{ll}\text { Islamic lending and microfinancing } & 39\end{array}$

$\begin{array}{ll}\text { References } & 40\end{array}$ 


\section{Abbreviations and acronyms}

$\begin{array}{ll}\text { AAAA } & \text { Addis Ababa Action Agenda } \\ \text { ACG } & \text { Arab Coordination Group } \\ \text { AGFUND } & \text { Arab Gulf Programme for Development } \\ \text { CGAP } & \text { Consultative Group to Assist the Poor } \\ \text { CRS } & \text { Creditor Reporting System } \\ \text { DAC } & \text { Development Assistance Committee } \\ \text { DEEP } & \text { Deprived Families Economic Empowerment Programme } \\ \text { GIZ } & \text { Deutsche Gesellschaft für Internationale Zusammenarbeit } \\ \text { IFRC } & \text { International Federation of Red Cross and Red Crescent Societies } \\ \text { IFFIm } & \text { International Finance Facility for Immunisation } \\ \text { IsDB } & \text { Islamic Development Bank } \\ \text { LDMC } & \text { Least developed member country } \\ \text { LLC } & \text { Lives and Livelihoods Fund } \\ \text { NGO } & \text { Non-governmental organisation } \\ \text { ODA } & \text { Official development assistance } \\ \text { OECD } & \text { Organisation for Economic Co-operation and Development } \\ \text { OIC } & \text { Organization of Islamic Countries } \\ \text { PIF } & \text { Public Investment Fund } \\ \text { SDGs } & \text { Sustainable Development Goals } \\ \text { SESRIC } & \text { Statistical, Economic and Social Research and Training Centre for Islamic } \\ \text { TOSSD } & \text { Countries } \\ \text { UK } & \text { Total official support for sustainable development } \\ \text { UN } & \text { United Kingdom } \\ \text { UNDP } & \text { United Nations } \\ \text { UNHCR } & \text { United Nations Development Programme } \\ \text { USD } & \text { United Nations High Commissioner for Refugees } \\ \text { WWF } & \text { United States Dollar } \\ & \text { World Waqf Foundation } \\ & \end{array}$




\section{Executive summary}

Islamic finance refers to the financing activities that comply with the sharia, or Islamic law. Its practical application takes the form of various concepts and instruments, by and large concerning the 57 members of the Organisation for Islamic Cooperation (OIC), which represents over 1.7 billion people, many of which are developing countries and fragile contexts. Islamic finance is worth USD 2.5 trillion in 2018, which is for the most part taking a commercial dimension, but a portion of this may also be applied to promote sustainable development. Whilst $21 \%$ of the OIC's population still live below the international poverty line, double the worldwide figure (Abdul Hamid, 2018[1]) using Islamic finance in Muslim-majority contexts may be socially, culturally and ethically more acceptable and relevant than other conventional forms of finance, including finance for development. It can promote low systemic risks and a sustainable financing system - particularly important for developing countries that have been piling debt.

Arab donors and rising Muslim-majority donors, such as Indonesia or Malaysia, make up the second largest block of development co-operation providers worldwide after the OECD Development Assistance Committee (DAC). At the same time, Arab donors reporting to the OECD disbursed USD 13 billion in ODA in 2018 (OECD, n.d.[2]), ${ }^{1}$ and only a fraction of this is delivered through Islamic finance. There are opportunities to accelerate the delivery of the Sustainable Development Goals (SDGs) through the development and use of several Islamic finance concepts and tools, notably some of the most promising ones, i.e. zakat, awqaf/waqf, sukuk and Islamic microfinancing.

This paper fleshes out some of these opportunities (and challenges), as well as highlights potential areas where Arab providers of development co-operation and DAC members can deepen their collaboration in order to mend the current SDG financing gap through raising awareness, promoting transparency and encouraging joint Arab-DAC partnerships.

\section{Awareness raising}

Most Islamic finance is operated by private actors, but there is growing interest among Muslim-majority governments and development co-operation practitioners to better regulate its collection and disbursement for development. The paper documents a number of nascent efforts, both within Muslim-majority developing countries and through development co-operation. These approaches deserve better study to understand how Islamic finance contributes to development, which approaches are better suited for particular contexts, such as those of fragility, and how partnerships among Arab and DAC providers could revert to the use or integrate Islamic finance considerations (e.g. through blending) for greater impact.

\footnotetext{
${ }^{1}$ No comprehensive data is available for 2018 at the time of writing. The Arab donors that report to the OECD are: Kuwait (including the Kuwait Fund for Arab Economic Development); Saudi Arabia (including the Saudi Fund for Development); the United Arab Emirates (including the Abu Dhabi Fund for Development); the Arab Bank for Economic Development in Africa (BADEA); the Arab Fund for Economic and Social Development; the Islamic Development Bank; and the OPEC Fund for International Development.
} 
Doing so can ultimately raise awareness and increase openness towards this mode of financing, as well as encourage the development of expertise in Islamic finance for development.

\section{Transparency}

The OECD can help build the evidence base on Islamic finance flows for development, building on its experience of collecting data from over 50 providers of development co-operation beyond the DAC. By reporting, the activities of Arab providers are recorded by the OECD, enhancing the transparency and efficiency of the international development co-operation system. It also enhances the visibility of the activities of Arab providers, e.g. by featuring these activities in OECD work. Currently, the only Islamic finance flows for development reported to the OECD are the activities of the Islamic Development Bank. However, even this information is incomplete, because the Bank does not report on amounts mobilised from the private sector for development purposes. Other Arab donors that also operate with Islamic finance tools (e.g. Arab Gulf Programme for Development, Arab Monetary Fund) could also to report to the OECD on their official development assistance using Islamic finance. In addition, all Arab providers could make use of the new statistical framework of total official support for sustainable development (TOSSD), which would track all Islamic finance operations, including those falling under the concept of ODA. To support Muslim-majority providers in reporting their Islamic finance flows for development, the DAC could engage with the OIC's Statistical Economic and Social Research and Training Centre for Islamic Countries (SESRIC).

\section{New Arab-DAC partnerships on Islamic finance}

Strong partnerships between Arab and DAC donors can help implement new forms of financing, including through the use of Islamic financing instruments, and can help expand the role of Islamic finance in the field of development co-operation. These partnerships could take the following form:

- Using grant finance from the DAC to leverage resources from private actors in Muslim countries, including with Arab donors and through Islamic financing tools for sustainable development purposes. Blending mechanisms of conventional and Islamic finance are possible and can promote sustainability, as well as financing viability.

- DAC members could partner with the Islamic Development Bank, as the institution leading on Islamic finance for development, e.g. to implement projects together or to co-ordinate activities on the ground. In turn, Arab providers could make greater use of the multilateral system by promoting the use of Islamic finance or the creation of dedicated vehicles within those institutions.

- Arab and DAC providers could convene a roundtable with private sector actors working with Islamic finance to explore options for delivering development objectives through Islamic finance. Discussions could include ways of ensuring that investments by sovereign wealth funds and pension funds reach developing countries through Islamic finance tools.

- Arab providers could collaborate with DAC members to raise awareness of the links between zakat and the SDGs amongst their own citizens, while DAC members could also do so within their own Muslim communities. For this collaboration to take root, governments could promote policy changes, e.g. by encouraging boards and shareholders of providing institutions to consider Islamic finance instruments, when using conventional development finance. 


\section{The contribution of Islamic finance to sustainable development}

This paper identifies ways in which Arab and OECD Development Assistance Committee (DAC) donors could harness the opportunities presented by Islamic finance to deliver the Sustainable Development Goals (SDGs). Whilst some DAC members have experience of working with Islamic finance, most of these experiences are still relatively small in scale and reflect a growing collaboration with Arab donors. International organisations and civil society have been more successful than DAC members in mobilising Islamic finance for development - yet there is potential for developing the joint collaboration and partnership among Arab and DAC providers through the use of Islamic finance.

\section{Islamic finance to deliver the Sustainable Development Goals}

To deliver the SDGs, the UN estimates that between USD 5 to 7 trillion per annum needs to be mobilised by 2030. Developing countries face an annual funding gap of USD 2.5 trillion to achieve the SDGs (UNSDG, 2018[3]). Low-income countries will require the largest increases in public expenditure relative to GDP to fill this gap. To increase the share of resources available for development purposes and to ensure that these resources reach those most in need, Islamic finance provides a novel option.

Islamic finance is worth USD 2.5 trillion in 2018 (DinarStandard, 2019 ${ }_{[4]}$ ), and is due to exceed USD 3 trillion by 2020 (Martínez-Solimán, 2017[5]) and USD 3.5 trillion by 2024 (DinarStandard, 2019 ${ }_{[4]}$ ). There are Islamic financial products and services in 50 Muslim and non-Muslim jurisdictions worldwide, spanning Malaysia, Dubai, Bahrain, and reaching into centres of conventional finance, trade and investment, such as London (RFI, 2019[6]). These activities are dominated by banking sector assets, which comprise nearly $75 \%$ of all activities, while capital markets at around $20 \%$ are another important segment (World Bank and Islamic Development Bank Group, 2017 $[7]$ ) (DinarStandard, 2019 ${ }_{[4]}$ ). Islamic finance has kept pace with the rapid changes in the financial markets, adopting fintech, cryptocurrencies and digital banking, for example. Future projections show that Islamic financing instruments will continue growing, driven by relatively high demographic growth (the global Muslim population is expected to grow from 1.7 billion in 2014 to 2.2 billion Muslims by 2030) and strong adherence to ethical values (with $76 \%$ of Muslims considering religion to be very important and $66 \%$ of Muslim consumers willing to pay more for ethical products, see (DinarStandard, $\left.\left.2019_{[4]}\right)\right)$.

The profile of Islamic finance in the global financial system is rising, notably following the global financial crisis of 2008 and the 'Arab Spring' in 2010. Islamic finance was seen as offering lower systemic risks and a sustainable financing system that could be more robust and resilient than conventional financing (Dridi and Hasan, 2010 $\left.{ }_{[8]}\right]$. To non-Muslims, Islamic finance can be seen as a form of socially responsible or ethical finance, although ethical and Islamic finance have both similarities and differences (RFI, 2019 $\left.{ }_{[6]}\right){ }^{2}$

\footnotetext{
${ }^{2}$ For example, the role of finance in adding value to the economy is more explicit in Islamic finance, as financial transactions are supported by genuine economic activity. Islamic finance also contains elements that support
} 
Concretely, Islamic finance is increasingly adopting sustainability criteria, so it is well positioned to maximise social impact and address the SDGs (DinarStandard, 2019 $9_{[4]}$ ). With concessional loans increasingly being favoured over grant financing by some donors (Klein and Harford, 2005[9]), there is a growing risk of developing countries piling up unsustainable levels of debt - with the IMF advising that $40 \%$ of low-income countries are at high risk of being unable to make payments on their public debt (Heilprin, $\left.2019_{[10]}\right)$. Developing countries therefore need a full suite of financing instruments to curb these trends, and Islamic financing options could improve debt sustainability.

Yet, the growth of Islamic finance has slowed somewhat in recent years, notably due to the fact that the economies of many Muslim-majority countries are dependent on commodities. Notwithstanding, its volumes are non-negligible and even a fraction of these, if better channelled towards development outcomes, could help fill the current SDG gap. There is now more research on how interpretation of Islamic finance concepts and tools can impact development (UNDP, 2019 ${ }_{[11]}$ ). To connect Islamic finance and the sustainable development agenda, a strategic approach is needed to (a) raise awareness amongst development practitioners of its potential; (b) set out the opportunities it presents and (c) identify barriers and gaps that prevent its further development. This strategic approach requires changes or adaptation of the operating environment of donors, some of which are already underway (e.g. donors are increasingly receptive to working with the private sector). In particular:

- DAC donors could conceive Islamic finance as more than a tool that is restricted to faith-based organisations and civil society; and recognise its value in both humanitarian and development responses. They could expand their partnership with Arab (and rising Muslim-majority) donors for the benefit of their partner countries.

- Arab (and rising Muslim-majority) donors could deepen their expertise in Islamic finance, as a way to increase their development co-operation activities and build stronger partnerships with developing countries. They could increase their leadership role in the development sector, notably through partnerships with DAC members.

Islamic finance is an emerging opportunity that could be looked at comprehensively by Arab and DAC donors and that could also be harnessed by other development partners, such as multilateral development organisations. It is one way in which donors can provide socio-politically and culturally appropriate and sensitive responses to development challenges to certain beneficiary countries - for example in some Muslim-majority countries with strong Islamic finance institutions (IRTI, 2017[12]). These beneficiaries would receive more context-sensitive development finance flows, which could be more effective and achieve greater impact - and be in line with the principles of the Global Partnership for Effective Development Cooperation. As highlighted in this paper, a handful of bilateral Arab and DAC donors and international organisations have started harnessing the opportunity of working through Islamic finance. Owing to the results achieved, this paper argues that more can be done in the future to ensure that a greater part of Islamic finance contributes to development outcomes.

\section{The Muslim world and Sharia}

Governments of Muslim-majority countries convene at the Organisation of Islamic Cooperation (OIC), which is the second largest inter-governmental organisation worldwide. The OIC has 57 members representing over 1.7 billion people globally (WorldData, n.d.[13]). The majority of OIC members are in the global South and represent developing countries with a diverse set of needs. The IsDB and the World Bank set out that 21 of the OIC's membership are least developed countries (World Bank and Islamic

sustainability (e.g. no harm for future generations, prohibition of speculative activities, any financial innovation has to be screened, discourages excessive leverage, etc.; see (RFI, 2019 $\left.9_{[6]}\right)$. Research further shows that Islamic financial criteria can generate value not just for responsible investors, but also for unconstrained investors (see (Gueckel, 2017[77])). 
Development Bank Group, $2017_{[7]}$ ) and $21 \%$ of the OIC's population still live below the international poverty line, double the worldwide figure (Abdul Hamid, 2018 $\left.{ }_{[1]}\right)$. OIC countries have major challenges in implementation of several Sustainable Development Goals, notably with regards to SDGs 2 (Zero Hunger), 3 (Good Health and Wellbeing), 5 (Gender Equality), 6 (Clean Water and Sanitation) and 16 (People, Justice and Institutions) (Bertelsmann Stiftung and Sustainable Development Solutions Network, 2019 [14]). There are currently 224 million people malnourished in OIC countries and 28 OIC countries rank among the world's 54 low-income food-deficit countries (FAOSTAT, 2020[15]). What is more, according to the OECD States of Fragility report (OECD, 2018 $\left.{ }_{[16]}\right), 29$ OIC member states can be considered fragile, with a population of 1.2 billion. As of 2010 , over 14 million people were internally displaced (SESRIC and IsDB, 2014[17]).

A common feature in the Muslim world is respect for sharia, the law derived from religious scriptures. Sharia seeks to create a fair, equitable and just society, as its purpose is realising human well-being by enhancing welfare (maslahah) and preventing harm (mafsadah). These translate into a common understanding of what is halal (permissible) and haram (prohibited). It can be said that most Islamic societies are attracted to the Quranic vision of a value-based economic order delivering justice and equality (UI Hassan, 2010[18]). Notwithstanding, different schools of thought within Islam have different interpretations, and these differences also extend to the field of Islamic finance. Islamic finance is one area of Sharia that has been ruled upon extensively and so has relatively clearer guidelines on how to manage financial resources and undertake business dealings. Organisations dealing with Islamic financial products have panels of religious scholars and jurists to ensure high levels of Sharia compliance. Some of the main characteristics of Islamic financing are:

- Prohibition of interest or 'riba' in financial transactions;

- Disapproval of speculation in the market or trading in money. Consequently, risks are commensurate with returns;

- Money has a commodity value; and

- Every transaction is linked to a real economy transaction or asset, in contrast to conventional finance, where no bounds constrain an operation. As a result, most Islamic finance transactions are asset-based in one way or another. ${ }^{3}$

Risk and profit are shared in transactions, which reduces volatility and promotes wealth creation among provider and recipient of Islamic finance. Proponents of the system argue that as goods have an intrinsic value, the system can provide better protection than conventional finance. It allows borrowers to budget effectively and to reduce levels of debt that can come from market uncertainties. Notwithstanding, interpretations of Islamic finance precepts can vary across jurisdictions. For example, despite interest being forbidden, in a limited number of cases, partners may add a fee to account for what would otherwise be termed as 'interest' in conventional financing. For example, in a qard loan, a service charge is introduced to cover the costs incurred by the lender, who would nonetheless be encouraged to be lenient if the borrower cannot repay on schedule. For effective implementation of sharia-compliant financial systems, high standards of governance, transparency, and vigilance by regulatory bodies are required to ensure the basic precepts are not lost during implementation.

Islamic finance is applicable and accessible to both Muslims and non-Muslims, but the focus here will be placed on OIC members. The OIC world does not represent a homogenous bloc. Political, social and economic contexts differ substantially from one country to another. For example, wealth distribution varies widely, with poverty being prevalent in sub-Saharan Africa whilst the Arabian Gulf countries are part of the high-income bracket. Similarly, financial inclusion rates in these markets is low and the IsDB sets out that

\footnotetext{
${ }^{3}$ For example, murabaha transactions engage in purchases and sales of a physical asset; ijara transactions are assetbased through a purchase undertaking by the originator; and mudaraba or musharaka transactions are equity-based contracts and thus forms of asset-light financing.
} 
over $72 \%$ of the population in OIC members are excluded from financial services (IsDB, 2018[19]). These markets affected but not always defined by Islamic finance tenets, with the World Bank setting out that $92 \%$ of adults (over 15 years of age) have bank accounts in Iran (World Bank, n.d.[20]), whereas in Sudan this figure is only $15 \%$ (World Bank, n.d.[21]). Similarly, there are differences in how much Islamic finance is used. For instance, according to some studies, the financial sectors of Iran and Sudan are $100 \%$ shariacompliant by law (and thus reviewed and managed by sharia-compliant boards centrally through government structures), whilst in Kuwait and Saudi Arabia, Islamic finance has approximately a $50 \%$ market share (COMCEC, 2019[22]). Some countries are developing robust ecosystems to operate in the Islamic finance area, while other countries are less active. For example, Uzbekistan is set to welcome Islamic finance to revamp its economy; Indonesia has a National Sharia Finance Committee and an Islamic Economy Masterplan for 2019-24, with the central goal of boosting the role of Islamic finance in driving economic growth; and Morocco issued its first sovereign sukuk for its own development (DinarStandard, 2019[4]).

\section{Islamic finance is complex and only some instruments can be used for development}

This paper focuses on Islamic social finance instruments and opportunities that are applicable and accessible to Arab and DAC donors. Simply put, Islamic finance has two branches, namely Islamic social finance and commercial Islamic banking. Islamic social finance is distinct but not separate from Islamic banking, as it is focused on generating social and economic gains, which links it closely to delivering development outcomes. Islamic social finance investments generate returns through education, healthcare, welfare, and infrastructure for those in need (INCEF, n.d.[23]). Commercial Islamic banking, which includes insurance, capital markets and asset management, seeks to generate financial returns, like the conventional banking sector, and does not necessarily seek development outcomes. Notwithstanding, donors could engage with Islamic banking to ensure they also contribute to sustainable development, e.g. when Islamic banks work with the private sector.

There are a variety of Islamic religious obligations like zakat (compulsory alms giving), sadaqa (voluntary alms giving) and waqflawqaf (charitable endowments) that could contribute to social finance - these are not Islamic finance instruments per se but are included in this analysis. Commercial Islamic banking transactions use instruments such as murabaha (cost-plus financing of a non-interest-bearing loan), which accounts for a large share of Islamic financing, ijara (leasing), mudarabah (capital and labour partnership) and musharaka (profit- and loss-sharing partnership). Islamic fixed income, known as sukuk, have been increasingly used in different parts of the world, although not all forms are used for social impact.

\section{Table 1.1. Overview of Islamic finance terms}

\begin{tabular}{|c|c|}
\hline Instrument & Description \\
\hline Zakat & $\begin{array}{l}\text { Alms-giving in Islam which is obligatory on all Muslims who meet certain wealth criteria. One of the five pillars } \\
\text { of Islam. }\end{array}$ \\
\hline Sadaqa & Voluntary alms-giving in Islam. \\
\hline Waqf /Awqaf & Endowment on property is made to a religious, educational, or charitable causes. \\
\hline Sukuk & $\begin{array}{l}\text { Islamic asset-based financial certificate, can be compared to conventional bonds (which are debt-, equity- } \\
\text { or quasi-equity based). }\end{array}$ \\
\hline Musharaka & Joint enterprise or partnership where partners share profits and losses. \\
\hline Murabaha & $\begin{array}{l}\text { Receivables created are trade receivables from the cost-plus sale, often structured to deliver similar } \\
\text { economic outcomes as a loan. }\end{array}$ \\
\hline Mudarabah & $\begin{array}{l}\text { Partnership contract where delegated authority is given to an agent to carry out trades and transactions. } \\
\text { Money is provided from one party and expertise/labour from the other. }\end{array}$ \\
\hline
\end{tabular}


Islamic finance and specifically Islamic social finance is well positioned to offer new forms of development assistance, with opportunities for both donors and beneficiaries. The following chapters will focus on those instruments with most potential for development co-operation, namely:

- Islamic social finance (zakat, waqf/awqaf);

- Islamic financing and microfinancing, including Islamic bonds (sukuk).

\section{Developing the Arab-DAC partnership around Islamic finance}

With surging demand for more financial resources for development and a desire to achieve an efficient allocation of resources, the international community is exploring alternative forms of financing. According to OECD statistics, Arab donors, including Arab multilateral institutions, disbursed close to USD 13 billion in 2018 - although there is no information about their magnitude and how these are reflected in official statistics; while DAC donors disbursed USD 139 billion in official development assistance (ODA) in 2018 (OECD, n.d.[2]). However, only a share of Arab donor activities can be considered as using Islamic finance for development. As of today, Islamic finance activities are not easily identifiable in the OECD development finance statistics or any other global database. In the current statistical classifications, financing modalities relating to Islamic finance activities are assimilated to standards grants, standard concessional loans and potentially other financial instruments without the possibility of isolating Islamic finance.

\section{Information on Islamic finance for development is limited}

Currently, there is limited information on Islamic finance for development, mainly accounting for the Islamic Development Bank activities. The IsDB activities are valued at USD 165 million in 2018 in gross ODA (that is, without removing concessional loan repayments to the Bank). In addition, the Bank disbursed USD 2.1 billion in gross other official flows (OOF). These amounts can be considered Islamic finance, as the Bank works solely through sharia-compliant financing. This explains why the IsDB leads the global development community on the use of Islamic finance and is a centre of excellence when it comes to developing Islamic finance instruments. Notwithstanding, the information available from the IsDB is incomplete. For example, the Bank does not report to the OECD on amounts mobilised from the private sector for development purposes with Islamic finance tools - a step that the Bank could consider. 


\section{Figure 1.1. Trends in Arab concessional financing}

Gross disbursements, 2018 constant prices

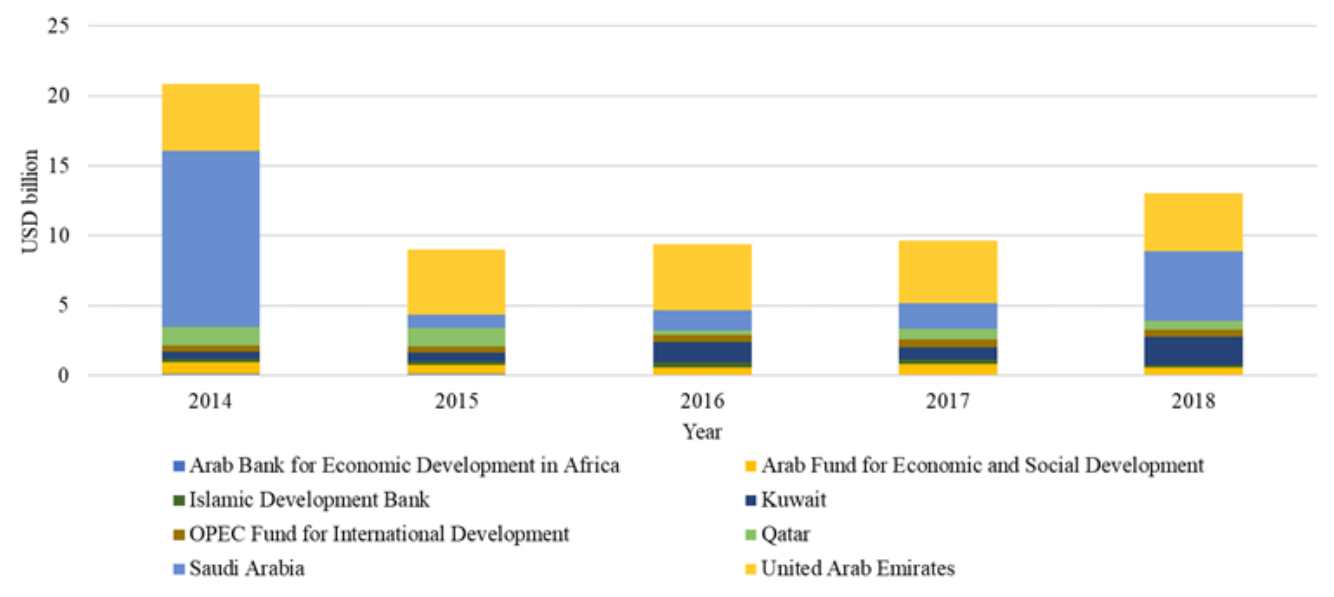

Note: The OPEC Fund and the Islamic Development Bank are global institutions but are considered here as Arab providers because of their membership in the Arab Coordination Group and because their main shareholders are Arab providers, such as Saudi Arabia. The data for Qatar is based on OECD estimates built on development co-operation reports by the Qatar Fund for Development. The 2015, 2016,2017 and 2018 data presented for Saudi Arabia are incomplete. Notably data on loans extended and grants from some Saudi entities are missing and the country is working towards completing the data. Data for 2014 is based on Saudi Arabia's previous reporting to the OECD on its development co-operation programme, which consisted of aggregate figures on humanitarian and development assistance by region, multilateral aid and loan disbursements and repayments by the Saudi Fund for Development. BADEA did not report data in 2016, 2017 and 2018, and the data for those years is based on its average contributions between 2014 and 2015.

Source: (OECD, n.d.[2]) Creditor Reporting System (database) https://stats.oecd.org//Index.aspx?.DataSetCode=CRS1.

In addition, but to a lesser extent, the Arab Gulf Programme for Development (AGFUND) and the Arab Monetary Fund also use Islamic finance as a part of their business. However, neither report to the OECD on their development finance flows.

The four major funds representing the four largest Arab bilateral donors, namely the Saudi Fund for Development, the Abu Dhabi Fund for Development, the Kuwait Fund for Arab Economic Development and the Qatar Fund for Development, have not pursued Islamic finance as a form of financing, as the IsDB is the best conduit for these countries, all of whom are IsDB shareholders. Notwithstanding, civil society in Kuwait, Qatar, Saudi Arabia and the United Arab Emirates are known to use Islamic finance in their operations. Some donors are included in the OECD database (e.g. Dubai Cares) but there is no way to understand whether these actors use Islamic finance or not.

When leveraging the effect of Islamic finance on private investments, neither Arab donors nor Islamic multilateral organisations report to the OECD on the amounts mobilised from the private sector. This is primarily due to Islamic principles around charitable giving (see next section). However, a 2018 multilateral development bank report on mobilisation (IFC, 2018[24]) suggests that the IsDB is an important player in private finance mobilisation in low- and middle-income countries. Joining other bilateral and multilateral providers in reporting mobilisation data to the OECD would not only contribute to improving the coverage of the OECD development finance statistics in general, but it would also greatly improve the visibility of Islamic finance and on its alignment with the 2030 Agenda. This is important because the private sector of many Arab countries are engaged in Islamic finance through their sustainability or corporate social responsibility efforts. For example, the Majid Al Futtaim, a shopping mall, communities, retail and leisure corporation operating across the Middle East, Africa and Asia, is listed as the world's first benchmark corporate green sukuk and first green sukuk issued by a corporate in the region, valued USD 600 million; (Futtaim, 2019[25]). Another example comes from the Islamic Fintech sector, which has seen recent 
developments, e.g. with Malaysia-based Islamic fintech start-up HelloGold partnering with Africa and China to manage micro-loans and land endowments (DinarStandard, 2019 $9_{[4]}$ ). The development impact of these Islamic finance initiatives ought to be better understood.

Many of the Gulf donors could also leverage financing from private charity. As will be seen later, obligatory annual contributions from Muslims (zakat) could also be used for charitable purposes in developing countries. In the United Arab Emirates, these are pooled in the Zakat Fund and zakat contributions are also disbursed or implemented as social welfare projects by many of the United Arab Emirates' donor organisations (MICAD and OECD, 2015[26]). There is, however, no information about their magnitude and how these are reflected in official statistics.

Arab and DAC donors are increasingly working in partnership, exploring ways to marry conventional and Islamic finance (such as in Germany, where GIZ is active in Islamic microfinancing projects), yet this information is also difficult to quantify.

The limited information on Islamic finance flows for development beyond the IsDB has to do with the fact that most funds are from private sources. Reporting, notably from resources channelled through official means, would enhance trust in the use of this form of financing. It would also help better explain how much Islamic finance is already contributing towards SDG-related activities. The new statistical framework of TOSSD, (see Box 1.1) represents a major opportunity to better reflect Islamic finance in international statistics. The TOSSD framework includes a specific data field called "Financing arrangement" that allows providers of development co-operation to report an activity as "Islamic finance". In a recent TOSSD data survey conducted from March-September 2019, Islamic finance activities were collected from the IsDB and Saudi Arabia. TOSSD holds great potential to collect even more Islamic finance flows as recent research also shows that some rising development providers (e.g. Indonesia) also provide Islamic finance (OECD, forthcoming $[27]$ ).

\section{Box 1.1. What is total official support for sustainable development?}

TOSSD is a two-pillar framework that tracks officially supported i) cross-border resource flows to developing countries and ii) global and regional expenditures, in support of development enablers, international public goods and global challenges. It measures resources provided by both emerging and traditional providers as well as multilateral institutions, including through South-South and triangular co-operation.

The primary objective of the TOSSD statistical framework is to promote greater transparency about the full array of officially supported resources provided in support of the 2030 Agenda, including official resources and resources mobilised from the private sector by official development finance interventions.

Moreover, TOSSD is expected to facilitate learning and co-ordination among developing countries and providers alike about how to access and combine resources most effectively. Importantly, TOSSD will support more informed policy discussions about the ultimate quality and impact of development finance. The measure will also provide insights about how the international community is financing international public goods. Finally, the measure is meant to mobilise additional resources above and beyond ODA.

The statistical features of TOSSD have been developed by the international community through an International Task Force established in 2017. The Task Force is comprised of 25 experts, representatives of the statistical and development co-operation communities and includes provider and partner countries, as well as international organisations. The Task Force concluded the first version of the TOSSD methodology in June 2019. Moreover, a data survey 
was launched in early 2019 to test the TOSSD concept and collect TOSSD data from a wide range of bilateral and multilateral providers of development co-operation.

The UN Inter Agency and Expert Group on SDG Indicators (IAEG-SDGs) reviewed a proposal to include TOSSD in the global SDG indicator framework in October 2019 and agreed that work would continue to further develop and refine the proposal. At its meeting in March 2020, the UN Statistical Commission supported the establishment of a UN working group to this effect, with a view to integrate this new measure of development support in line with the 2030 Agenda with the global SDG indicator framework in 2022. TOSSD data will provide the evidence and experience essential for further refining the methodology.

The Arab-DAC Dialogue on Development is one way for the two communities to enhance their collaboration. The Dialogue seeks to build strong partnerships between the 10 Arab Coordination Group (ACG) members and the 30 DAC members and 6 participants (including Kuwait, Qatar, Saudi Arabia and the United Arab Emirates). This is facilitated by sharing lessons learnt and experiences, identifying opportunities for collaboration and engaging on policy priorities of joint interest like women's economic empowerment, education, or water and sanitation. Strong individual partnerships between Arab and DAC donors can therefore help implement new forms of financing effectively, including through the use of Islamic financing instruments, and can help expand the role of Islamic finance in the field of development cooperation. 


\title{
2. Islamic social finance
}

\author{
Islamic social philanthropy and charitable giving
}

Muslims are encouraged to benefit their immediate communities and ensure that the poor are provided for in the first instance. Islamic finance seeks to redistribute assets amongst communities, ensuring that there is a fair distribution of wealth. Islamic social finance concepts, such as zakat and awqaf, are a means of delivering on this imperative through sustained charitable means and is one of the obligations that Muslims have from a religious perspective (and the only one having a financial dimension). As such, the redistributive and social equality elements of Islamic social finance have an important role to play in realising SDG1, 'End poverty in all its forms everywhere', in particular. ${ }^{4}$

DinarStandard estimates global zakat at USD 76 billion (DinarStandard, 2019 $9_{[4]}$ ), while the UNHCR calculates that global zakat could exceed USD 300 billion (UNHCR, 2019 ${ }_{[28]}$ ) and the IsDB calculates global zakat to be worth over USD 1 trillion per annum (Rehman, 2019[29]). In turn, DinarStandard considers awqaf assets to be USD 410 billion in 2016 (DinarStandard, 2019 ${ }_{[4]}$ ), while the Dubai government notes that awqaf could also amount up to USD 1 trillion per annum (Vizcaino, 2013[30]) and Finterra estimates these to be USD 3 trillion, with an estimated return of $5 \%$ or USD 150 billion annually, which could be used for socio-economic goals (Finterra, 2020[31]). The broad range of estimates and varying sizes point to the limited availability of quality data on these concepts. This is especially true for awqaf, where a sizeable share is in land and property (some waqf have been active for centuries). Not surprisingly, zakat and awqaf are insufficiently organised to achieve development goals. They remain under-reported in development figures and are not captured in development finance flows, as seen earlier for Islamic finance more generally. In addition to the reasons mentioned earlier, there are specific reasons for both tools to be relatively under-reported:

- For zakat, this is partly due to the fact that some zakat is spent in-country (thus not relevant from a development co-operation perspective, although this could be seen as a form of domestic resource mobilisation contributing to development in some contexts) and because a large proportion of charitable giving is done privately through informal means (i.e. doing good but not talking about it). Creating mechanisms for it to be effectively channelled towards SDG-related activities could position zakat as an effective means of raising capital for both humanitarian and development responses, as will be shown below (see Box 2.1).

- Awqaf are relatively large but may have been managed inefficiently, generating low social returns (Nadia Abas and Raji, 2018[32]). Raising awareness on the potential social returns that awqaf can deliver, building on current good practice, could make it attractive as an investment opportunity and lead to better integration into the global development community.

Despite the prevalence of these two Islamic finance mechanisms, only a few developing countries have explored the untapped source of raising revenue through them for social assistance and poverty alleviation (IRTI, 2017[12]). A number of experiences are being made that point at the growth and potential of the two figures in the future.

\footnotetext{
${ }^{4}$ Sadaqa, whilst not obligatory, accounts for voluntary alms giving and follows the same principles of zakat and will not be covered in this report.
} 


\section{Zakat}

\section{Box 2.1. Zakat overview}

- One of the five pillars of Islam, obligatory alms-giving in Islam for all Muslims who meet certain wealth criteria (nisab).

- Calculated as $2.5 \%$ or $1 / 40$ of the accumulated net wealth of personal assets (but not including home) over the course of a lunar (Islamic) year. It can be financial or in-kind (e.g. crops, livestock).

- Collection differs according to geographic location. In some Muslim-majority countries, the government assumes responsibility for collection and distribution locally (Indonesia, Malaysia, United Arab Emirates). Zakat can also be collected in the form of a tax (Qatar). In other countries, zakat collection is not organised by the state (Nigeria, South Africa).

- Official zakat delivery systems are not fully developed across DAC members, so Muslim citizens in DAC countries will commonly (but not only) use Islamic nongovernmental organisations (NGOs) that offer zakat services internationally. Conversely, amongst Arabian Gulf donors, governments can offer this provision through official channels. For example, the UNHCR can collect and distribute zakat as a secular NGO.

- Depending on the context, zakat will be channelled through unofficial means, independent agencies or mosques. Zakat can also be given directly to a beneficiary.

- Zakat is given to those most in need and so is usually provided as humanitarian assistance (grant finance), rather than longer term development assistance (concessional loans).

- In particular, zakat can be effectively aligned with social SDGs, such as SDG1 'No Poverty', SDG2 'Zero Hunger', SDG3 'Good Health and Well-Being', SDG4 'Quality Education', SDG6 'Clean Water and Sanitation', SDG8 'Decent Work and Economic Growth' and SDG10 'Reduced Inequalities'. The use of zakat has so far limited for environment-related SDGs.

The impact of zakat for development still needs to be better understood.

\section{The challenge}

As outlined above, zakat still needs to be better captured, harnessed and channelled to respond effectively to the SDGs. In Islam, zakat and alms-giving is accompanied with humility. It is emphasised that to do good with wealth is better than ostentatious display, which has no social value. In practice, Muslims commonly channel alms through informal structures, giving directly to beneficiaries or using mosques and local charities or organisations to disburse contributions to those most in need. Such giving is not ordinarily recorded in official systems. Additionally, if one gives zakat to family or friends, this will not be captured. As a result, knowledge around levels of wealth in Muslim societies is low, especially amongst high net worth individuals as an individual's net worth can be calculated according to how much zakat they give (2.5\% of cumulative wealth).

As zakat can be given directly to beneficiaries, it is difficult to calculate accurately its magnitude and impact. As long as zakat distribution remains sharia-compliant, there is scope to align its expenditure with development objectives. Until recently, zakat directed to international development was not commonplace 
but today this is changing. Indeed, this can happen through national zakat agencies, international organisation platforms that capture zakat, or through the work of civil society organisations:

- A number of Muslim-majority countries, including Qatar, the United Arab Emirates, Indonesia or Malaysia, have zakat agencies that operate as a part of government. They collect zakat. Ordinarily this is done to meet domestic needs and good practice examples can be seen in Malaysia. Malaysia's method of zakat collection (see Box 2.2) highlights how a government can efficiently administer this important function and deliver on behalf of citizens. However, not all Muslim-majority countries have introduced the system of zakat, which is considered a private activity, thus making it difficult to assess its effectiveness in poverty alleviation (IRTI, 2017 $\left.{ }_{[12]}\right)$.

\section{Box 2.2. The Zakat Collection Center - PPZ, Malaysia}

Founded in 1990 by the Government, Malaysia's Zakat Collection Center (PPZ) has sought to make the payment of zakat easier for Muslims in Malaysia, e.g. by reforming the governance of the Center or by implementing reforms to automatically calculate amounts due. Over time, the PPZ has run awareness raising campaigns to inform the Malaysian Muslim population around obligations around zakat. In doing so, trust in the system has increased, as seen in the $20 \%$ rise in collection rates each year during the period 2005 to 2008 (Wahid, 2014 ${ }_{[33]}$ ). The Zakat Collection Center operates within Malaysia and does not disburse funds abroad yet, still lessons could be extracted from its successful domestic operations.

Source: (Zakat, n.d.[34]), Zakat, http://dx.doi.org/www.zakat.com.my.

These agencies do not always operate internationally but could do so through an international window, integrated within the country's development co-operation activities. Indeed, this is the case of Indonesia where activities, including scholarships, humanitarian aid, refugee support, food aid, and co-operation related to peace and security, are delivered with zakat funds to other countries through its National Amil Zakat Agency (BAZNAS, see Box 2.3). Another example is the United Arab Emirate's Zakat Fund, which can disburse funds for domestic donors to implement projects abroad (MICAD and OECD, 2015[26]). Similar institutions could be established in DAC members with substantial Muslim communities to collect national zakat and contribute to international development. 


\section{Box 2.3. Badan Amil Zakat Nasional - BAZNAS, Indonesia}

The National Amil Zakat Agency (BAZNAS) is the official and only Indonesian body collecting and distributing zakat and alms (ZIS) in Indonesia. BAZNAS was formed by the government based on a Presidential Decree. BAZNAS was declared as a non-structural government institution that is independent and is accountable to the President, through the Minister of Religion. BAZNAS, together with the government, is responsible for overseeing the management of zakat which is based on the sharia and the principles of trustworthiness, expediency, justice, legal certainty and accountability. In 2017, BAZNAS collected over USD 11 million from across 150000 Indonesian citizens and distributed over USD 7 million across 305000 people in Indonesia. BAZNAS operates primarily at a national level but has provided support in response to specific international issues, like refugees fleeing Myanmar (UNDP Indonesia, 2017[35]). Recently, BAZNAS initiated a cost-sharing partnership with the Global Environmental Facility, whereby it channelled USD 350000 zakat funds for providing power to people living in remote rural villages in Jambi, Sumatra and four micro-hydro power plants to produce a total of 180000 people with electricity.

Source: BAZNAS (n.d.), Badan Amil Zakat Nasional, https://baznas.go.id.

International organisations started working with zakat financing. One of the highest profile and accessible platforms internationally is managed by the United Nations High Commission for Refugees (UNHCR). It launched its Refugee Zakat Fund in 2019, replacing UNHCR's existing zakat programme to transform it into a global fund to aid the most vulnerable displaced populations, while meeting the needs of Islamic institutions and individuals in fulfilling their social responsibility duties (UNHCR, 2019[35]). The activities include cash assistance and concentrate in Jordan, Lebanon, Yemen, Iraq, Mauritania and Egypt, as well as Bangladesh and Myanmar (UNHCR, 2019 $9_{[36]}$ ). Despite the increased transparency and profile that an organisation like UNHCR can offer, such platforms are still not the preferred method of alms giving for Muslims. In fact, these platforms can be perceived as impersonal, compared to more established ways to channel zakat. Additionally, issues around efficiency in the UN system can hamper the ability to secure the confidence of some individual donors. ${ }^{5}$ Notwithstanding, UNHCR is using the Fund to bridge its required funding gap of USD 209 million to support over 150000 people. It raised USD 38.1 million in the first half of 2019, surpassing the original target of USD 26 million, which shows the appetite (and success) for this kind of initiatives in the Muslim world.

Civil society has also harnessed zakat. Organisations such as the International Federation of Red Cross and Red Crescent Societies (IFRC) have used Islamic Finance effectively (see Box 2.4), e.g. to deliver drought relief in Kenya in collaboration with Malaysia. Such a triangular co-operation partnership, where Kenya benefited from Malaysia's expertise, was possible due to the IFRC's use of zakat funding from Malaysia. IFRC effectively routed existing financial flows, ensuring low transaction costs for programme delivery. Another example is the United Kingdom's National Zakat Foundation (see Box 2.5).

A number of studies show that, even under a number of restrictive assumptions, zakat alone could be sufficient to cover the poverty gap and be used for poverty alleviation in developing countries (IRTI, 2017 $[12])$. More concrete studies in Bangladesh and Pakistan show that the integration of zakat (and waqf) into national development plans could contribute substantially to their implementation (IRTI, 2017[12]).

\footnotetext{
${ }^{5}$ These points were highlighted during interviews conducted with senior officials for the purpose of this paper.
} 


\section{Box 2.4. Case study: International Federation Red Cross and Red Crescent Societies (IFRC) and Kenya Red Cross - Malaysian zakat to help communities in Kenya recover from drought}

A Red Cross pilot project in one of the poorest districts in Kenya has demonstrated the untapped contribution that Islamic social financing can make in the area of development cooperation. Funds raised through the zakat mechanism can make a real and lasting difference for people of all faiths and backgrounds with a USD 1.2 million contribution, making returns of USD 20 million from crop sales.

\section{Background}

One of the worst droughts in Kenya's history reached a crisis point in early 2017 with an estimated 2.7 million people needing relief assistance. Recognising the growing difficulties involved in raising emergency funds, the International Federation of Red Cross and Red Crescent (IFRC) and the Kenya Red Cross approached the Zakat Council of the Malaysian State of Perlis, an organisation with a track record of using Islamic social finance instruments such as zakat to benefit communities in need. The Zakat Council (which sits at the sub-national level) provided a substantial contribution of zakat funding (USD 1.2 million) to the drought assistance programme. That contribution was allocated to the county of Kitui, in southern central Kenya. The location met the requirements for funding by the Malaysian Council because the population of Kitui showed a clear need for humanitarian assistance, qualifying them under the asnaf, or categories of people eligible for zakat distribution.

\section{Intervention}

The programme developed by the Kenya Red Cross tackled water access and cash-crop issues. It included the repairing of existing bore holes and pumps and the installation of new ones, to bring the total up to 30 . These provide clean water to the county, as well as livelihood opportunities in selling and distributing water. The funds also allowed the purchase of certified seeds that were distributed to 175000 subsistence farming families.

\section{Results}

As a result of the zakat-supported intervention, access to clean water and sustainable cash crops was made possible for more than 1 million people across the county of Kitui. Water kiosks and distribution businesses provided employment and funding for the maintenance of the water pumps. Crop market sales contributed to community welfare, providing cash for food, health care and education, as well as seeds to pay for the cost of purchasing the initial seeds received and for seeds for the next crop. This helped raise funds for investment in the neighbouring county of Garissa, which was suffering similar hardship. In keeping with the zakat principles, the initial recipient thus became a contributor to the development of its community.

All in all, funding the initiative demonstrated that zakat contributions can be used for international humanitarian and development projects. It also showed that Islamic social finance can provide charitable disaster relief and contribute to a country's development.

Source: (IFRC, 2018[37]), Beyond Charity - the transformative power of zakat in humanitarian crisis, http://media.ifrc.org/innovation/wpcontent/uploads/sites/9/2018/08/Kenya_case_study_2018_003.pdf 
Direct remittances are another way of transmitting zakat to developing countries. In DAC countries, there are often sizeable Muslim populations with links to developing countries. These populations often produce high levels of remittances, and some of these remittances could be classed as zakat. For example in 201516, over USD 1.7 billion was sent to Pakistan from the United Kingdom, accounting for $13 \%$ of total remittances received in that country, but the zakat part of this is unknown (Migration Observatory, 2016[38]). Indeed, there are no reliable means of tracking these remittances, with global remittances from the United Kingdom in 2014, estimated to be between USD 1.8 and 20 billion (Migration Observatory, 2016[38]). The absence of a system to track remittances effectively highlights the importance of having a global solution to do so. This solution needs to reflect the highly diverse needs of Muslim populations when sending remittances.

\section{Box 2.5. National Zakat Foundation - NZF, United Kingdom}

Founded in 2011, NZF is an independent NGO seeking to deliver relief to Muslims in need in the United Kingdom through its Economic Empowerment Programme. The programme provides basic essentials as well as job training, covers legal costs and provides debt relief (National Zakat Foundation, n.d.[39]). It has raised over USD 10 million in this time and helped over 2500 people. In the United Kingdom, during Ramadan, the Muslim Charities Forum calculates that over USD 130 million is raised annually through zakat and charitable giving, which is disbursed both in the United Kingdom and abroad (through remittances).

Source: National Zakat Foundation (n.d.), Our History, https://www.nzf.org.uk/News/ViewArticle/4240.

\section{The opportunity}

The potential of zakat to support development remains unrealised - for example, according to the Islamic Research and Training Institute, the actual zakat collected in Indonesia corresponds to $0.025 \%$ of its GDP against a potential of $1.59 \%$ of GDP. In Pakistan, the corresponding figures are $0.06 \%$ and $1.74 \%$ of its GDP; while in Malaysia, the actual zakat collected is $0.24 \%$ of GDP against a potential of $1.11 \%$ of GDP (IRTI, 2017[12]). These cases are among the most successful in zakat mobilisation efforts among developing countries and suggest that, in some contexts, zakat can be a sustainable source of finance for development (notably in South-East Asia, contrary to sub-Saharan African countries where the collection of zakat may be more volatile). The IsDB has now set out how the resource gap in some countries with Muslim minorities could be well covered by effective resource mobilisation of charitable giving (World Bank and Islamic Development Bank Group, 2017[7]). The solution proposed is to effectively tap into zakat flows and use them to deliver on the SDGs. For that to happen, a holistic approach is required to change donor behaviour and adapt reporting and regulatory frameworks to collect zakat-related information and capture funds.

While preserving principles of humility around charitable giving, both Arab and DAC donors could raise the profile of the SDGs with Muslims around the world and highlight SDG alignment with the principles of zakat. In particular, they could explain the SDGs and their effect on countries where zakat flows could be disbursed. For example, zakat could contribute to international humanitarian responses and to the delivery of international public goods like fighting climate change or ensuring safe migration. Doing so would encourage Muslims to understand the potential impact of their charitable giving for the Sustainable Development Goals. Ideally, increased zakat-giving would happen through official channels. The IsDB has being doing this effectively, most recently with the launch of a philanthropic fund with the Global Partnership for Education (see Box 2.6), which highlights the contribution of Islamic Financing to SDG 4, which aims to deliver inclusive and equitable quality education and promotes lifelong learning opportunities for all. 


\section{Box 2.6. Global Partnership for Education and Islamic Development Bank Global Muslim Philanthropy Fund for Children}

In 2019, the IsDB and UNICEF announced their intent to develop a Global Muslim Philanthropy Fund for Children. The fund aims to mobilise Islamic giving, including through philanthropic and zakat resources, towards humanitarian and resilience development programmes that ensure the well-being of children in IsDB member countries. IsDB and UNICEF are now developing the fund, alongside key partners, in anticipation of a formal launch. The fund will provide children with access to safe water, nutrition, education, health and protection.

Source: UNICEF (2019), Islamic Development Bank and UNICEF to establish a Global Muslim Philanthropy Fund for Children, https://www.unicef.org/press-releases/islamic-development-bank-and-unicef-establish-global-muslim-philanthropy-fund.

Official zakat-giving requires improved organisation, notably to enhance trust in where funds go to and how they are spent. Donors could promote the development of vehicles or even institutions that allow Muslim individuals to make charitable donations in a way that speaks to their religious belief. This could contribute to a better allocation of global financial resources for development, both official and private sources. The initial costs of setting up such institutions and creating an enabling environment for these to operate, especially in DAC countries, could be high. Appropriate legal, fiscal and banking safeguards would need to be introduced to ensure compliance with sharia and to ensure trust of Muslim citizens.

If zakat is to deliver on development goals, it is critical that current flows are better recorded. Since amounts given in zakat are expected to grow, it is only through better accounting of these flows that the full power of zakat can be harnessed. To deliver this effect, collaboration with development partners, especially through fora like the Arab-DAC dialogue could be useful. In some regions, further awareness on zakat could also be a useful way to leverage this financial resource for development, notably in Sub-Saharan Africa where capacity and awareness are low (IRTI, 2017 $\left.{ }_{[12]}\right)$. 


\section{Awqaf}

\section{Box 2.7. Waqf (Awqaf): An overview}

- Islamic endowment on an asset for a religious, educational or charitable cause, with the requirement to deliver returns to the community. For example, financing housing, schools and hospitals may be possible through awqaf in developing countries.

- Real estate is the usual form of waqf but other movable, financial and intangible assets could also fall in this category, provided the legal framework of a country allows for it.

- Endowments are made in perpetuity with no intention of assets being reclaimed. Rather the endowment seeks to deliver a social good to a given community over time and deliver returns accordingly.

- Awqaf can act as vehicles for both public and private giving if managed according to sharia. As long as they are established with a view to delivering a social benefit to a community, the financial resources can come from government or private donors, business or communities.

- Awqaf can contribute to social infrastructure in developing countries over a long period of time, which could be used for humanitarian or development purposes.

- In particular awqaf can contribute to SDG4 'Quality Education', SDG6 'Clean Water and Sanitation', SDG7 'Affordable and Clean Energy' and SDG11 'Sustainable Cities and Communities'.

- For awqaf to be able to do so, then the SDGs need to be included in the waqf deed. However, most waqf are not yet referencing the SDGs and their impact on development needs further research.

\section{The challenge}

Waqf, or the plural Awqaf (used interchangeably in this paper), mobilises large amounts of private and public finance in Islamic social finance. The waqf is an effective means of distributing wealth to a community and persons over a long period of time. This can translate into providing social infrastructure, such as housing, basic infrastructure, schools or hospitals (see Box 2.7). Despite limited data on awqaf, a recent estimate of potential awqaf in the case of Indonesia shows that it could generate up to $0.85 \%$ of its GDP (IRTI, 2017 [12]).

Awqaf generally work effectively in providing public goods to a population but their application in a development context has been limited to date. There are a number of issues where reform would make them an attractive financing tool for development. Indeed, the management of these funds often generates low social returns. In the United Kingdom, preferences for giving to charity (obligatory zakat) rather than investing in awqaf has reduced the prevalence of this financial instrument (Shahbaz Mirza, 2017[40]), because the instrument as a whole has not been delivering high-value social benefits. However, the United Kingdom is well placed to demonstrate how awqaf can contribute to sustainable development, in particular to understand when its use can generate financial and social returns (Shahbaz Mirza, 2017 ${ }_{[40]}$ ). This finding also aligns with recent growth in social impact investment, which is looking to achieve strong social returns and high levels of social impact (OECD, 2015[41]).

Whilst awqaf offer consistent returns, stability and predictability, a major hindering issue has been that investments are made in perpetuity and so there are limitations around how easily money can be divested and how actively funds need to be managed to generate returns. Investors traditionally look for 
mechanisms that mobilise finance and in turn deliver a positive return. By having endowments that offer little flexibility or control to investors, there are few incentives to encourage stronger investment. Many of the waqf assets in existence have conditions from the original donor, which remain in effect in perpetuity (and many awqaf have been in that form for centuries). The religious nature of these restrictions makes modifying the purpose difficult, without significant reputational risk for the waqf trustees.

As such, establishing high-profile awqaf, with strong social returns and high levels of social impact, can increase both the appetite for more risk-averse investors to engage with this financial instrument. As highlighted in Box 2.8, the IsDB has invested heavily in developing and delivering awqaf effectively since 1979. The different awqaf funds that the IsDB manages respond to a number of development challenges and highlight the significant financial resources that can be mobilised through this channel, sometimes combined with other financial instruments. For example, the IsDB's Special Fund for Poverty has secured commitment from OIC member countries and other donors to resource a USD 10 billion fund which taps into domestic awqaf, amongst others for the purposes of poverty reduction (IsDB, 2007 $7_{[42]}$ ). These funds are usually used to finance the construction of buildings in waqf lands, real estate development projects to enhance existing waqf buildings and increase income assets, to support social activities, notably in the field of education or health over long periods of time.

\section{Box 2.8. The IsDB's Awqaf Funds}

- The IsDB established a Waqf Fund in 1979 to cater to the social sector needs of the Muslim communities and organisations in non-member countries and least developed member countries (LDMCs). By 2007, the size of the Waqf Fund had reached USD 1.4 billion comprising the principal amount of Waqf Fund (USD 1.1 billion), balance of the Special Assistance Account USD 64 million and the Special Account for LDMCs USD 182.2 million. In Bangladesh, for example, the IsDB funded the purchase of community property with USD 6 million, with the financial streams deriving from this investment social helping to fund programmes, notably in the education sector.

- In 2001, the IsDB established the World Waqf Foundation (WWF), in collaboration with waqf organisations run by OIC member countries, NGOs, and philanthropists. The objectives of the WWF are to: (i) promote and activate awqaf with the view to contributing to the cultural, social and economic development of member countries and Muslim communities, and to alleviate hardship among the poor, as well as to sponsor and support waqf organisations with expertise; (ii) support organisations, projects, programmes and activities in the educational, health, social, and cultural fields; (iii) provide support in the conduct of studies and scientific research in the field of waqf; and (iv) assist countries and organisations in drafting waqf legislation.

- In 2005, the IsDB established a fund for poverty reduction. This is a waqf with a cap of USD 10 billion from member countries. In addition to the voluntary contribution from member countries, the fund seeks to tap into zakat and awqaf resources and philanthropist donations.

Source: IsDB (2007), Islamic Development Bank Group in Brief, https:/www.isdb.org/sites/default/files/media/documents/201812/IDB_In_Brief_1428H.pdf.

However, beyond these good practice examples, there is scant evidence on how awqaf is currently delivering on development, let alone the SDGs. A number of countries are setting up or have set up a ministry or department to manage waqf funds (IRTI, 2017 $[12]$ ), which could be the entry point to harness this financial figure. Yet to contribute to the SDGs, the awqaf sector needs to become a more attractive 
activity and a suitable vehicle for governments and donors. A logical starting point is the design of a stronger enabling environment to establish, manage and deliver awqaf in a more flexible manner for development purposes.

\section{The opportunity}

The critical feature of waqf is that investments are made in perpetuity and can generate stable returns for both Muslims and non-Muslims. From a donor perspective, the fact that waqf does not engage in speculation means that investments are secure, thus promoting trust and transparency. This demands that resources are managed well but also makes awqaf potentially useful in delivering critical social infrastructure. According to (IRTI, 2017 $[12]$ ), however, social waqf has not been mobilised as much as religious waqf, although there are signs pointing towards more social waqf now (e.g. cash waqf in Malaysia, Indonesia and Singapore or the redevelopment of waqf assets to generate returns in Sudan).

The OECD has looked at social impact investing recently and at the role of Islamic financing in its 2015 report (OECD, 2015[41]). Social impact investment is nascent in the Middle East and North African region, although a shortage of financial intermediaries coupled with lack of awareness is hindering the growth of this market. Islamic finance was seen as vital for developing the social impact investing market in this region. The principles of Islamic finance overlap with those of social impact investing (see (RFI, 2019[6])) and initiatives like the Global Islamic Finance and Impact Investing Platform will play an important role in directing this finance towards social impact investing. In the context of the DAC, harnessing awqaf could go hand-in-hand with current developments in the social impact investment sector, to ensure that functions of awqaf can deliver high levels of social impact. This would result in awqaf becoming a more common vehicle for delivery of large amounts of sustainable Islamic finance. For Arab donors, raising the profile of existing awqaf and looking to link more explicitly awqaf with the SDGs would show leadership when it comes to innovative and sustainable forms of financing. One way for the DAC to harness this financial vehicle would be to partner with the ISDB to raise awareness on awqaf and to learn more about how it mobilises funds through this tool. This could then lead the IsDB to create windows that combine awqaf from OIC members with conventional development finance from DAC members, provided this is offered in a sharia-compliant way.

\section{Way forward}

There is a missed opportunity if readily available zakat and awqaf funds are not used to fill the current development finance gap. Islamic social finance can ensure that more financial resources are mobilised in a sustainable way for the SDGs, in a way that is more inclusive. Defining a space for Islamic finance in the global development architecture and narrative could mobilise Muslims around the world to contribute to development and the SDGs. Donors have a responsibility to shape this architecture and narrative to include Islamic finance and to ensure that instruments like zakat and awqaf are part of their development finance portfolio, when appropriate.

Harnessing zakat and awqaf flows, in particular zakat (e.g. following the Indonesian or Malaysian models of having an agency to collect, report and distribute zakat), could be a first step in mobilising these flows towards the SDGs and towards underfunded humanitarian and development appeals, notably in fragile contexts:

- For DAC members, working with partners in the Muslim world to acquaint themselves with existing models of zakat collection would be useful. If there is interest in working with Islamic finance tools this could lead to novel forms of Islamic and conventional finance for development being combined or even to the mandates of national development of agencies (or extending the mandates of existing development co-operation agencies or units to work with Islamic finance and partner with Arab donors). This could be interesting in member countries where Muslim populations are 
significant. Arab and DAC donors can also work with international organisations and civil society to set up platforms to mobilise and deliver zakat in a way that ensures more transparency, cost efficiency and effectiveness. The most important aspect of a zakat agency or platform is that it remains accessible to the Muslim donor and tailored to local Muslim priorities. Finally, the platforms themselves would need to have their costs covered through other sources other than zakat to ensure that all zakat is received by the designated recipient.

- Regarding awqaf, donors could tap into these funds after regulatory reforms, by enabling the issuance of awqaf-linked grants for specific humanitarian or development appeals and responses. For example, this could be done by treating UN humanitarian or development appeals or treating grants for the SDGs as possible waqf beneficiaries. Whilst abiding with sharia regulations around awqaf, this could be an effective way of ensuring emergency appeals are not underfunded, given the large amounts of awqaf funds currently unused in Muslim countries, and to contribute to lower levels of sovereign debt in developing countries. Additionally, awqaf could be managed by international organisations, building on or working to develop the model started by the IsDB. 


\title{
3. Islamic financing and microfinancing
}

\begin{abstract}
Sukuk (a sharia-compliant asset-based security) and Islamic finance lending are two areas which can be used to deliver infrastructure and large-scale programmes in Muslim-majority countries and beyond. Sukuk present low risks and guaranteed returns for investors (see Box 3.1). Islamic microfinance programmes can offer solutions in areas where financial inclusion is low, by reducing both risk and debt levels while promoting equality, social welfare and economic security. These are two Islamic finance instruments that can be used effectively to respond to the SDGs. The DAC can do more to build its competence in this area, working with Arab organisations like the IsDB and engaging with the private sector to scale the use of these instruments, notably to integrate current innovation in the financial technology sphere (e.g. blockchain technology, see (Blossom Finance, 2020[43] )).
\end{abstract}

\section{Sukuk}

\section{Box 3.1. Sukuk}

- Sukuk is generally asset-based securities and function like bonds in conventional finance, which are debt-based. An event of default would trigger a purchase undertaking for the asset, which returns the asset to the obligor in exchange for a payment liability to investors.

- They give ownership in a designated asset or pool of assets, which then gives access to a share of revenue or income. It is necessary to have some degree of ownership of a fixed asset (property, land or commodity) to issue a sukuk.

- Sukuk delivers equivalent return to conventional bonds and their present value of issue and outstanding sukuk are affected by changes in interest rates in newly issued bonds.

- Sukuk can be used to deliver concessional loans in a development context. They can be combined with grant financing from conventional and Islamic sources, provided Arab and DAC donors work together. Conventional investors can invest in sukuk, but shariacompliant funds are in most cases be segregated from any interest-based forms of finance.

- Sukuk can be effectively aligned with SDG3 'Good Health and Well-Being', SDG4 'Quality Education', SDG5 'Gender Equality', SDG6 'Clean Water and Sanitation', SDG7 'Affordable and Clean Energy', SDG8 'Decent Work and Economic Growth', SDG9 'Industry Innovation and Infrastructure', SDG11 'Sustainable Cities and Communities', SDG12 'Responsible Consumption and Production', SDG13 'Climate Action', SDG14 'Life Below Water, SDG15 'Life on Land' and SDG16 'Peace Justice and Strong Institutions'.

- Commercial Islamic financing is not yet sufficiently contributing to social and environmental goals and impact, although the growth of green and social sukuk points to better integration of the SDGs in Islamic finance activities. 


\section{The challenge}

Sukuk is becoming a vital instrument used by both sovereign and corporate actors for resource mobilisation (World Bank and Islamic Development Bank Group, 2017[7]). Specifically, sukuk and other forms of Islamic financing could help respond to the current needs in infrastructure and help finance large-scale programmes in partner countries. It is noteworthy that the current financial shortage in many developing countries in these areas is large. The OIC assesses, from a sample of $13 \mathrm{OIC}$ member countries, that infrastructure needs will amount to USD 7.2 trillion over 2016-40. With investments currently estimated at USD 5.6 trillion, the resulting deficit will be USD 1.6 trillion over that same period (COMCEC, 2019 $9_{[44]}$ ). At a global level, the gap is even larger, as the World Economic Forum notes that the global infrastructure finance gap will amount to USD 15 trillion by 2040.

In 2016, Islamic banking assets represented USD 1.45 trillion and sukuk amounted to a further USD 341 billion (Ahmed, 2017[45]). The sukuk market is still growing, even though it is developing at a fast pace and holds potential for further development. Currently, it has issuance of USD 123 billion per year, with total

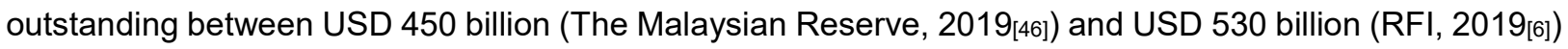
- up from USD 6 billion in 2004 (RFI, 2019 $\left.9_{[6]}\right)$. Developing countries have recently been issuing sukuks. For example, Senegal issued the largest sukuk with the Islamic Corporation for Development worth USD 208 million in 2014, followed by a second one in 2016 worth USD 350 million. The funds were used for urban development, water supply, road and street lighting programmes. Other countries followed suit in Africa, including South Africa, Cote d'Ivoire, or Togo, and several countries are in the midst of preparing legislation to facilitate sukuk issuances. Another example is Malaysia, which launched the world's first green sukuk by Tadau Energy under the Malaysian Securities Commission's Sustainable and Responsible Investment (SRI) Sukuk Framework; or Indonesia, which also launched a green sukuk in 2018 and set up the Tropical Landscapes Finance Facility in 2016 to leverage private long-term finance for projects and companies that stimulate green growth and improve rural livelihoods. In 2019 , sukuk issuance has been driving growth of Islamic finance as a whole, with e.g. over USD 1 billion in infrastructure projects linked with sharia-compliant financing issued in Indonesia and USD 1.3 billion issued by the IsDB (DinarStandard, 2019). In fact, the IsDB has been issuing sukuk since 2003, using the market mobilised funding to complement its own equity and, to date, the IsDB has raised over USD 21 billion through sukuk to finance development projects in its member countries. Interestingly, too, the IsDB recently launched its first green sukuk, raising EUR 1 billion for climate change and green projects in the Bank's member countries (e.g. renewable energy, clean transportation, energy efficiency, pollution prevention and control, environmentally sustainable management, land use and sustainable water and wastewater management). Yet, despite these volumes, the sector has traditionally been seen as a niche activity by Western economies. This is especially true beyond the United Kingdom, which has the largest Islamic finance sector of any OECD country. For example, as a global financial centre, the City of London and the UK government launched the first sovereign-backed sukuk outside of the Muslim world in 2014, worth USD 250 million (Goverment of the United Kingdom, 2014[47]). This was followed in 2018 with the first bank-issued public sukuk in a non-Muslim country - by the United Kingdom's Al Rayan Bank.

However, engaging private sector investors is critical to ensuring delivery of the SDGs (SDGF, n.d.[48]). In commercial Islamic finance, some are taking steps to ensure their operations are linked with the SDGs, with important repercussions in developing countries. For example, the Bahrain based Al Baraka Banking Group has linked its 2016-2020 Goals to the SDGs, making Al Baraka one of the first global financial institutions to make progress towards the SDGs (see Box 3.2) (UNDP, 2016 $6_{[49]}$ ). In 2019, moreover, Al Baraka Banking Group became the first bank in western Asia (and the first commercial Islamic finance bank) to commit to the UN Principles for Responsible Banking, pledging USD 197 million for 2019-20 in support of renewable energy and energy efficiency projects in the bank's operating countries, including Jordan, Syrian Arab Republic, Iraq or Lebanon (UNEP, 2019[50]). Another example is Malaysia's CIMB Islamic Bank, which also adopted responsible finance practices in its operations and strategy (RFI, 2019[6]). This was spurred through its Islamic finance subsidiary, CIMB Islamic, and participation in Bank Negara 
Malaysia's Value Based Intermediation Community of Practitioners to incorporate sustainability as one of its five key strategic pillars.

The lack of incentives for the private sector to work in the development sector has meant that donors typically struggle to mobilise the financial resources of the private sector in many developing Muslimmajority countries. This has been hampered by weak regulatory frameworks that govern infrastructure and large-scale investment programmes (EIB, 2016 $\left.{ }_{[51]}\right)$. By overcoming this challenge, and building on the good practices observed in some commercial Islamic finance operators, donors that want to or that already work with the private sector could explore the use of commercial Islamic finance tools, such as sukuk. By doing so, donors could help attract other large private actors to work with these instruments. For example, donors could work with sovereign wealth funds and pension funds, for them to align their incentives with those of the SDGs, through Islamic finance.

\section{Box 3.2. Al Baraka pledges USD 635 million towards achieving SDGs as part of its social responsibility strategy}

Al Baraka Banking Group's 2015 Social Responsibility Report includes Goals for 2016-20. These are linked to the SDG (notably on job creation, education, and healthcare), making AI Baraka one of the first global financial institutions to make progress in this area. The Al Baraka Goals seek to:

- Create over 51000 jobs by 2020 through financing a number of businesses and projects in the countries where Al Baraka operates.

- Finance and support over USD 434 million in various healthcare projects and initiatives.

- Finance and support up to USD 191 million in education-related projects and activities.

Al Baraka Banking Group is licensed as an Islamic wholesale bank by the Central Bank of Bahrain, listed on Bahrain Bourse and Nasdaq Dubai stock exchanges. It is a leading international Islamic banking group providing services in countries with a population totalling around one billion. Al Baraka offers retail, corporate, treasury and investment banking services, strictly in accordance with the principles of the sharia. The authorised capital of Al Baraka is USD 1.5 billion, while total equity is at about USD 2.1 billion. The Group has a wide geographical presence in the form of subsidiary banking units and representative offices in fifteen countries, which in turn provide their services through over 600 branches. Al Baraka currently has a strong presence in Turkey, Jordan, Egypt, Algeria, Tunisia, Sudan, Bahrain, Pakistan, South Africa, Lebanon, Syria, Iraq and Saudi Arabia, and has two representative offices in Indonesia and Libya.

Source: UNDP (2016), Al Baraka pledges \$635 million towards achieving UN Sustainable Development Goals as part of its Social Responsibility Strategy, http://www.bh.undp.org/content/bahrain/en/home/presscenter/articles/2016/05/19/al-baraka-pledges-635-milliontowards-achieving-un-sustainable-development-goals-as-part-of-its-social-responsibility-strategy-html.

\section{The opportunity}

Sukuk and sharia-compliant lending can help reduce levels of sovereign debt and provide sustainable forms of financing. Sukuk in particular offers a means to work better with the private sector, providing alternatives to conventional debt financing. DAC members can learn from the first experiences that developing countries are making with sukuk, including with green sukuk, and with their own experiences in developing commercial Islamic finance tools - notably building on the United Kingdom example. These 
experiences have demonstrated the potential of Islamic finance in attracting private investment and made the United Kingdom a reference point for donors seeking sharia-compliant investments. Increasing use of these instruments across other DAC members with significant banking sectors, and to do so for development purposes, could have positive ripple effects.

Combining Islamic and non-Islamic forms of finance is relatively new in the development sector, given gaps in regulatory frameworks, limited awareness amongst donors of how Islamic finance can be used and with Arab-DAC partnerships still being limited in number. Yet, as highlighted in Box 3.3, the combination of Islamic and non-Islamic finance can deliver fruitful results. The IsDB's Lives and Livelihoods Fund brings together different types of donors and pools grant funding from Arab donors and the Bill and Melinda Gates Foundation, while leveraging large amounts of sharia-compliant concessional finance from the IsDB. In doing so, the Fund has both political influence and access to the Arab donors, consolidates the IsDB's leadership in the Islamic finance space, while enhancing co-ordination with one of the world's largest philanthropic organisations.

\section{Box 3.3. The Lives and Livelihoods Fund}

In 2016, the IsDB and development co-operation partners launched a USD 2.5 billion Lives and Livelihoods Fund (LLF) to help the poorest people in the least developed countries in the IsDB's membership to lead healthier and more productive lives. The Fund serves 33 IsDB member countries. The LLF donor partners are the Abu Dhabi Fund for Development, the Bill and Melinda Gates Foundation, the Islamic Solidarity Fund for Development, the King Salman Humanitarian Aid and Relief Centre, the United Kingdom's Department for International Development and the Qatar Fund for Development.

The LLF invests in key drivers of poverty, namely the health $(20 \%-60 \%$ of the total funding allocation), agriculture $(20 \%-60 \%$ of the total funding allocation) and basic infrastructure sectors (maximum $20 \%$ of funding allocation). The LLF provides access to affordable financing for social development projects. It does so by pooling grant resources from regional and international donors with market-based ordinary project financing to offer highly concessional funding that targets previously unreachable sub-sectors and project areas. For projects in least developed countries, LLF offers 35\% grant portions and 65\% IsDB Ordinary Capital Resource financing. Since IMF rules allow lower middle-income countries to borrow at market rates, the LLF offers packages of $10 \%$ grant portion and $90 \%$ IsDB ordinary financing, which makes the financing offered considerable cheaper for the recipient countries. The financial package results in substantially more funds, at concessional rates, made available for social development projects in areas where they are most needed.

Source: ISDB (n.d.), Lives and Livelihoods Fund, https://www.isdb.org/partnership/lives-and-livelihoods-fund.

Ensuring that large investors, such as sovereign wealth funds and pension funds, think of the SDGs in their investment strategies and consider development returns can have a massive impact in mobilising the wider investor community to think of development issues. However, sovereign wealth funds rarely invest in Islamic finance - particularly through Islamic asset management, which is an area still underdeveloped. Some funds may finance some of their investments through sharia-compliant financing but this is not commonplace, as they are often sensitive to costs and returns. One exception is Masdar, which has used sharia-compliant financing for renewable energy projects in the United Arab Emirates, but that ought to pave the way for further sharia-compliant investments in clean energy through public-private models worldwide (Masdar, 2017[52]). By engaging these large investors with sharia-compliant investments in developing contexts, governments could mobilise additional low-risk financial resources that would 
otherwise not be delivering returns. To do this, Arab and DAC donors could consider convening major investors to see how to integrate the SDGs through Islamic finance. One particular example is Saudi Arabia's Public Investment Fund, which has started aligning with the SDGs (see Box 3.4).

\section{Box 3.4. Saudi Arabia's Public Investment Fund (PIF)}

The PIF is due to become one of the world's largest sovereign wealth funds (Alathary, 2013 $\left.{ }_{[53]}\right)$. One SDG-aligned part of PIF is the Saudi Agricultural and Livestock Investment Company, which invests in food security-related projects. Whilst it looks to deliver financial returns, nationally and internationally, more can be done to ensure that its investments deliver development returns. PIF could maximise return on investments further by using Islamic finance and thus support Saudi Arabia, which is also one of the largest donors of development assistance in the Muslim world, in developing a whole-of-government, coherent development approach. This would ensure that PIF works in concert with the humanitarian and development arms of the Saudi government. If Saudi Arabia linked explicitly all of its PIF investments to the SDGs, this would have significant impact in encouraging others globally to follow suit, and could have a substantial impact on infrastructure projects or other large-scale programmes in developing countries.

The IsDB, as well as the World Bank, the Vaccine Alliance, GAVI, or the International Finance Corporation are making use of sukuk to mobilise funds. For example, the International Finance Facility for Immunisation worked with the ISDB to raise a USD 50 million sukuk to fund immunisation programmes and GAVI itself issued a sukuk that raised USD 700 million to protect children against preventable diseases (see Box 3.5). DAC members could also consider using sukuk to mobilise finance towards social infrastructure.

\section{Box 3.5. The IFFIm, GAVI and IsDB sukuk}

In 2019, the International Finance Facility for Immunisation (IFFIm) completed a private placement sukuk transaction with the IsDB. The sukuk raised USD 50 million to accelerate funding for immunisation programmes that save children's lives in the world's poorest countries. The sukuk, a certificate that complies with Islamic financing principles, was issued by IFFIm, with IsDB as the sole investor. The First Abu Dhabi Bank acted as placement agent on the transaction. This marked IFFIm's third sukuk, furthering IFFIm's presence in Islamic capital markets and building awareness and support for GAVI programmes amongst Gulf investors. Two previous sukuk issuances raised USD 500 million (2014) and USD 200 million (2015). These amounts could be seen as 'social impact investment on a grand scale.'

IFFIm raises funds for GAVI's immunisation and health strengthening programmes by issuing vaccine bonds and sukuk in the international capital markets. IFFIm's bonds and sukuk are supported by legally binding, long-term grants (approximately USD 6.5 billion) from 10 sovereign donors. The World Bank Treasury acts as IFFIm's Treasury Manager.

Source: IFFIm (2019), IFFIm issues sukuk to the Islamic Development Bank, https://www.iffim.org/library/news/press-releases/2019/iffimissues-sukuk-to-the-islamic-development-bankl.

To be effective, however, countries that have used sukuk in the Muslim world could be encouraged by DAC members to align their issuance with the SDGs to ensure that globally, both private and public sectors are working coherently to address development issues. At the same time, DAC members could pilot the issuance of sukuk for development as well, using the IsDB's Model Sukuk Law and Guidelines, which could 
help overcome some of the hurdles behind this tool (i.e. liquidity issues and limited active trading; buy and hold strategy by major investors due to limited supply; lack of regulatory support in a number of countries; or lack of harmonised sukuk structures).

\section{Islamic microfinance}

When seeking to address issues of social development, the levels of financial inclusion have a direct impact on how successful any programming is in the long term. Financial inclusion can give underserved communities a link into existing financial systems by reducing poverty and have wider-reaching economic and social benefits. With rising fragility and higher levels of refugee populations, more could be done to ensure donor responses in the area of financial inclusion. The benefits and impact of increased financial inclusion are sharia-compliant.

\section{The challenge}

Before the humanitarian crisis in Yemen, the Consultative Group to Assist the Poor (CGAP) set out that the "challenges associated with the demographic reality in Yemen include poor infrastructure, a dearth of formal financial services, widespread illiteracy, and a lack of consensus among the country's Islamic scholars about what makes a financial product sharia-compliant" (Alathary, 2013[53]]). These challenges are not unique to Yemen and can be considered more widely across the Muslim world (IRTI, 2008[54]). Until recently, sharia-compliant instruments have excluded individuals who would like to have access to Islamic finance and, as such, Islamic microfinance would be an effective way to promote inclusion (especially compared to conventional microfinance, see (IRTI, 2008 ${ }_{[54]}$ )), notably for women (Mohieldin et al., 2011 [55]). Access to finance is particularly important in fragile contexts, although further research would be needed to determine when Islamic finance would have more impact than conventional financing (Range and Kaiser-Yücel, 2016[56] $)^{6}$

Islamic microfinance works differently than other forms of sharia-compliant lending, which are usually tailored for larger scale lending. Islamic microfinance offers direct financial access to individuals and its mechanisms and structures are more amenable. Islamic microfinance often creates a direct link between donors and beneficiaries (although microfinance funds also exist and donors may also channel funds through microfinance institutions), unlike sukuk or other forms of Islamic lending, which require governmental or institutional engagement. As Germany's Gesellschaft für Internationale Zusammenarbeit (GIZ) sets out, over 400 million Muslims could have increased access to financial systems through Islamic microfinance. This would help poverty reduction amongst OIC members (GIZ, $\left.2014_{[57]}\right)$, where $72 \%$ of people living in Muslim-majority countries are not using formal financial services (CGAP, 2008 ${ }_{[58]}$ ). However, the CGAP estimates that in 2007 Islamic microfinance had a total estimated global outreach of only 380000 customers and accounted for only an estimated $0.5 \%$ (based on an estimated 77 million microcredit clients) of total microfinance outreach (CGAP, 2008 ${ }_{[58]}$ ). Notwithstanding, the GIZ considers the demand for Islamic microfinance to be high globally and some countries have taken steps to harnessing these specialised services. For example, the Standing Committee for Economic and Commercial Cooperation of the OIC highlights that there were over 3000 Islamic Savings and Loan co-operatives or

\footnotetext{
${ }^{6}$ Islamic finance demand studies have shown that about a third to a half of citizens in Arab countries refrain from using conventional financial services, yet researchers also show that religion may not always be a major barrier to explain account ownership. A study in Jordan not only showed that loan take-up may be higher when Islamic finance alternatives exist, but also that overall loan uptake may be lower due to the 'paradox of choice', whereby adding the choice of Islamic finance to the mix of options available to consumers, may actually cause people to avoid making any choice. In some cases, it may be valuable to fully substitute Islamic by conventional finance, as long as it is delivered in a way that is beneficial for the clients and when there is more latent demand for Islamic compared to conventional microfinance, which may not always be the case (Range and Kaiser-Yücel, 2016).
} 
BMTs in Indonesia in 2016, with consolidated assets of more than USD 100 million, employing more than 30000 workers, more than $40 \%$ of whom are women. BMTs served 2 million depositors and distributed micro credit to more than 1.5 million micro entrepreneurs (COMCEC, 2016[59]).

The low levels of Islamic microfinance are explained by the fact that the supply of microfinance is concentrated in a few countries. Moreover, there are few institutions delivering it with a development purpose, and regulatory frameworks for this tool need to evolve. Most operations, take place at the national level and supporting the institutions capable of working at a local level and/or supporting the expansion of such institutions to work in other developing contexts could increase their development impact. Current financial technology is not yet incorporating sharia-compliant microfinance solutions. While mobile banking technology has been recently thriving, notably in many developing country contexts, solutions that incorporate Islamic financing instruments are relatively rare (despite OIC countries having a high mobile penetration rate (DinarStandard, 2019[4] )). The delivery of sharia-compliant financial solutions through mobile technology similar to Orange-Pay in Senegal or M-PESA in Kenya (Vodafone, n.d.[60]), especially in low-income countries, could heighten financial inclusion in Muslim-majority countries. The Global Islamic Fintech Report of 2019 noted a lack of access to capital as the biggest barrier to scaling of Islamic fintech companies, which could spur the growth of Islamic microfinance, notably in Southeast Asian countries (Elipses, 2019[61]). The IsDB launched a 'Fintech Islamic Finance Challenge' in 2019 to source new innovative solutions that engage with Islamic finance systems, including microfinancing (IsDB FinTech, n.d.[62]).

\section{The opportunity}

Delivering projects that are appropriate to local contexts is critical but is specifically pertinent when it comes to addressing issues of financial inclusion, notably through Islamic microfinance. A study by the Islamic Research and Training Institute found that a number of donors were already engaged in Islamic microfinance programmes in 2008 (e.g. UNDP, Germany's KfW, see (IRTI, 2008[54])). More recently, Switzerland and AGFUND signed a memorandum of understanding to this effect in 2018 (AGFUND, 2018[63]), strengthening their commitment to deliver more effective Islamic microfinance solutions; while AGFUND became a board member of the Swiss Capacity Building Facility. This partnership engaged the Swiss finance and insurance sector, and has three projects in the pipeline. Another recent example in this domain is the UNDP's DEEP programme (see Box 3.6), around which a number of Arab and DAC donors convened to support the UNDP's delivery of sharia-compliant microfinancing in the West Bank and Gaza Strip. The programme has demonstrated that by using microfinancing, social development indicators can improve in a Muslim-majority context. Lessons from these experiences could be taken and similar methods could be tested more widely. 


\section{Box 3.6. UNDP's Deprived Families Economic Empowerment Programme (DEEP)}

UNDP's DEEP programme seeks to improve livelihood outcomes for poor and vulnerable households in the West Bank and Gaza Strip and to enable them to escape poverty. Specifically, the programme has two purposes:

- Poor and vulnerable households become economically empowered and resilient; and

- An enabling institutional framework for poverty alleviation is developed, promoting economic partnerships with and among the poor and enhancing their resilience.

This model aimed at revitalising the economy of the West Bank and Gaza Strip through selfemployment and micro-enterprise development. An Islamic microfinance component was integrated and delivered the following results:

- A total of 6190 micro- and small-enterprises received financing through partner microfinance institutions (MFIs).

- DEEP provided technical assistance to MFIs, which resulted in expanding community outreach with new rural branches, promoting pro-poor targeting among MFIs, and providing technical assistance to develop MFI human resources.

- A comprehensive awareness campaign was launched in all areas of the West Bank and Gaza Strip to promote pro-poor Islamic financing products, and to attract previously excluded clients.

DEEP brings together the UNDP, the IsDB, the Swiss Agency for Development and Cooperation, Qatar's Education Above All Foundation - Al Fakhoora Programme, the Government of Japan, the OPEC Fund for International Development, the Arab Fund for Economic and Social Development, the Swedish International Development Cooperation, and the Government of New Zealand. Together, these donors have contributed over USD 94 million since 2012. DEEP was awarded the AGFUND International Prize for Pioneering Human Development Projects in 2018

Source: UNDP (n.d.), Palestinian Families Economic Empowerment Programme (DEEP), http://www.ps.undp.org/content/papp/en/home/projects/deep.html.

Arab and DAC donors working on financial inclusion could consider sharia-compliant tools, especially when supporting the development of fintech solutions. Ensuring that there are sharia-compliant options available, not just conventional microfinance options, can ensure that programmes are able to take root in the Muslim world. Harnessing fintech solutions can have a considerable effect in ensuring impact in some of the world's most fragile contexts, such as Syria or Yemen. In particular, leveraging technical expertise of donors engaged in Islamic microfinance can ensure that Arab and DAC donors can deliver more effective solutions when using microfinance in their activities.

\section{Way forward}

Arab and DAC donors could work effectively together and build stronger alliances with the private sector using Islamic finance instruments such as sukuk and microfinance. Doing so would ensure a more targeted response in Muslim-majority countries. Private sector champions of Islamic finance could be mobilised to deliver the SDGs, which would raise the profile of Islamic tools and where both Arab and DAC members could show leadership. Specific donors will play a more prominent role in taking forward this engagement, building on their past experiences and good practices. Ultimately, a more inclusive, coherent community 
of partners delivering the SDGs can ensure that issues of financial inclusion can be addressed through collaboration.

DAC members could combine their conventional finance with Islamic forms of financing to deliver economic infrastructure and large programmes. Building exposure and understanding of different types of Islamic lending has two benefits. Firstly, it broadens and strengthens donor expertise in the financial sector, as they provide better tailored products. Secondly, it offers more appropriate, SDG-aligned instruments for Muslim-majority countries. In addition, mobilising large investors (e.g. sovereign wealth funds and pension funds) from DAC members and the Muslim world could (a) help develop partnerships with the private sector; (b) encourage other investors to engage in development co-operation; and (c) engage investors from the Muslim world to leverage political support to deliver development results in Muslim-majority countries. Having a positive impact on rates of financial inclusion, especially in fragile contexts could be done through Islamic microfinance, provided programming include sharia-compliant instruments. 


\section{Conclusions}

Islamic finance has not been harnessed fully by all Arab and DAC donors. In particular, this could be done by deepening expertise and understanding in a number of areas, especially in Islamic social finance. This could have a real impact in addressing the financing gap of the SDGs, co-ordinating international donor efforts through strengthened partnerships and increasing the relevance of development and humanitarian responses according to local contexts.

Most Islamic finance concepts and tools are mainly implemented by private actors, although there is growing interest in public activities to look at how these concepts and tools can foster sustainable development, through direct application of such public activities or indirectly through regulation changes (i.e. to develop Islamic capital markets and to ensure these are aligned with sustainable development objectives). For Islamic finance to take root in the development agenda and be properly accounted for, donors could perceive Islamic finance as something that is aligned with the SDGs. Addressing issues around language and acceptance of this new form of financing could raise awareness among donors, notably the DAC, and build upon existing successful experiences from donors in harnessing Islamic finance (e.g. individual work of some Arab donors; agencies and platforms that operate internationally; Arab-DAC partnership pilots). Raising the profile of Islamic finance for development could help update the current framework behind the use of these financial tools.

Increased co-ordination and strengthened partnerships between Arab and DAC donors are important to delivering the SDGs. The Arab donors, in particular, represent a critical partner with rising global presence. Working in concert with these partners, sharing expertise and pooling resources can promote innovation. Yet, to continue developing these partnerships through the use of Islamic finance, engaging Muslim populations (and other Muslim-majority rising donors) will be central to its success. Public actors could encourage changes at the policy level, e.g. by encouraging boards and shareholders to think about Islamic finance instruments, when using conventional development finance, or the other way around for Islamic finance users to incorporate sustainable development motivations and to blend finance from both perspectives. One element here would be to develop the capacity of both sides, as well as raising their awareness, on these possibilities. The Responsible Finance and Investment Foundation, for example, would be a good resource for DAC donors looking for capacity building around Islamic social finance.

Islamic finance offers something that has not been fully taken into consideration by the global development community. Donors could drive forward the integration of Islamic finance into the development narrative. As such, this paper has proposed a set of action areas for future collaboration between Arab and DAC donors:

\section{Zakat}

- Arab and DAC donors could raise awareness of the links between zakat and the SDGs with Arab and other Islamic donors and their citizens, while DAC members could also do so domestically with their Muslim communities. For example, DAC members could convene Muslim leaders to raise the profile of the SDGs, understand the incentives around giving and how zakat can best be channelled towards development objectives. 
- Institutionally, Arab and DAC donors could create (or extend the mandates of existing) agencies and platforms or tap into existing ones to access zakat funds and explore how current models could be scaled up.

- Arab and DAC donors could work on improving the tracking of zakat flows being collected and distributed globally. For example, the regulation of zakat needs to change to ensure that charitable organisations and those receiving charitable funds are adhering to high levels of transparency and reporting.

\section{Awqaf}

- Arab and DAC donors could explore the possibility of using waqf to respond to humanitarian and development appeals through the UN, or SDG-compatible awqaf. DAC members, in particular, could work with the IsDB to understand how to design awqaf vehicles for development. Both sets of donors could also raise awareness on how awqaf could help deliver the SDGs.

- Arab donors could improve the collection and reporting of awqaf data so that the total value of these assets is known.

\section{Islamic lending and microfinancing}

- Arab and DAC donors could explore working together in the areas of Islamic lending, e.g. sukuk and microfinance. Arab donors could raise awareness on the benefits and possibilities of these tools to deliver the SDGs, notably in Muslim-majority countries.

- The DAC, with Arab donors, could lead a roundtable with the private sector to explore how actors could support the delivery of development objectives through Islamic finance. Fintech companies and Islamic finance could be targeted for this dialogue, as well as Islamic financial institutions' sharia boards to build trust of the Muslim populations who could be using products that combine conventional and Islamic finance. RFI Foundation, for example, could support in these initiatives, as it can mobilise a broad stakeholder group of stakeholders at domestic and global levels for discussions about Islamic finance and the SDGs. 


\section{References}

Abdul Hamid, Z. (2018), Transforming OIC states member, https://www.nst.com.my/opinion/columnists/2018/04/355053/transforming-oic-states-member.

AGFUND (2018), AGFUND and the Swiss Agency sign MoU to support financial inclusion, http://agfund.org/news/33029/.

Ahmed, H. (2017), Contribution of Islamic Finance to the 2030 Agenda for Sustainable Development, https://www.un.org/esa/ffd/high-level-conference-on-ffd-and-2030-agenda/wpcontent/uploads/sites/4/2017/11/Background-Paper Islamic-Finance.pdf.

Alathary, A. (2013), Islamic Microfinance in Yemen: Challenges and Opportunities, https://www.cgap.org/blog/islamic-microfinance-yemen-challenges-and-opportunities.

BAZNAS (n.d.), Badan Amil Zakat Nasional, https://baznas.go.id.

Bertelsmann Stiftung and Sustainable Development Solutions Network (2019), Sustainable Development Report 2019: Transformations to achieve the Sustainable Development Goals.

Blossom Finance (2020), World-First Blockchain Sukuk Reports 12.94\% Annualized Profit, https://blossomfinance.com/press/world-first-blockchain-sukuk-reports-12-94-annualizedprofit.

CGAP (2008), Islamic Microfinance: An Emerging Market Niche, https://www.cgap.org/sites/default/files/CGAP-Focus-Note-Islamic-Microfinance-AnEmerging-Market-Niche-Aug-2008.pdf.

COMCEC (2019), Infrastructure Financing through Islamic Finance in the Islamic Countries, http://www.comcec.org/fr/wp-content/uploads/2019/04/35FC-FINANCE-12th-M..pdf.

COMCEC (2019), Infrastructure Financing through Islamic Finance in the Islamic Countries, http://www.sbb.gov.tr/wp-content/uploads/2019/06/Infrastructure-Financing-through-IslamicFinance-in-the-OIC-Member-Countries.pdf.

COMCEC (2016), Developing Islamic Finance Strategies in the OIC Member Countries, http://www.sbb.gov.tr/wpcontent/uploads/2018/11/Developing Islamic Finance Strategies in the OIC Member Cou ntries\%E2\%80\%8B.pdf.

DinarStandard (2019), State of the Global Islamic Economy Report 2019/20: Driving the Islamic Economy Revolution 4.0, https://cdn.salaamgateway.com/special-coverage/sgie19-20/fullreport.pdf. 
Dridi, J. and M. Hasan (2010), The Effects of the Global Crisis on Islamic and Conventional Banks: A Comparative Study.

EIB (2016), What's holding back the private sector in MENA? Lessons from the Enterprise Survey, https://www.eib.org/attachments/efs/econ mena enterprise survey en.pdf.

Elipses (2019), The Global Islamic Fintech Report, December 2019, https://cdn.salaamgateway.com/special-coverage/islamic-fintech-2019/full-report.pdf.

FAOSTAT (2020), Food and Agriculture data.

Finterra (2020), Waqf Chain.

Futtaim, M. (2019), World's First Benchmark Corporate Green Sukuk, https://www.majidalfuttaim.com/en/media-centre/press-releases/2019/05/majid-al-futtaimlists-world-s-first-benchmark-corporate-green-sukuk--on-nasdaq-dubai.

GIZ (2014), Toward Inclusive Islamic Finance - Insights from GIZ, http://microfinancemena.org/wp-content/uploads/2017/02/GIZ-2014-Toward-Inclusive-Islamic-Finance.pdf.

Goverment of the United Kingdom (2014), Government issues first Islamic bond, https://www.gov.uk/government/news/government-issues-first-islamic-bond.

Gueckel, C. (2017), How can Responsible Investors Benefit from Islamic Criteria?, https://papers.ssrn.com/sol3/papers.cfm?abstract id=2918849.

Heilprin, J. (2019), IMF wary of goverments piling up debt, https://aretenews.com/imf-wary-ofgovernments-piling-up-debt/.

IFC (2018), Mobilization of Private Finance by Multilateral Development Banks and Development Finance Institutions,

https://www.ifc.org/wps/wcm/connect/publications ext content/ifc external publication site/p ublications listing page/2018 mdb-mobilization-report.

IFFIm (2019), IFFIm issues sukuk to the Islamic Development Bank, https://www.iffim.org/library/news/press-releases/2019/iffim-issues-sukuk-to-the-islamicdevelopment-bank/.

IFRC (2018), Beyond Charity - the transformative, http://media.ifrc.org/innovation/wpcontent/uploads/sites/9/2018/08/Kenya case study 2018 003.pdf.

INCEF (n.d.), Islamic Social Finance, https://www.inceif.org/islamic-social-finance/.

IRTI (2017), Practical Means of Integrating Zakat and Waqf into the Poverty Reduction Agenda of OIC Member Countries.

IRTI (2008), Islamic Microfinance Development: Challenges and Initiatives.

IsDB (2018), Financial Inclusion - The Role of Islamic Finance,

https://www.tcmb.gov.tr/wps/wcm/connect/918421f3-90da-4d02-929f-

35b5bc660adc/Session+2.2+-+Financial+Inclusion++Islamic+Development+Bank+Group.pdf?MOD=AJPERES\&CVID=.

IsDB (2007), Islamic Development Bank Group in Brief, https://www.isdb.org/sites/default/files/media/documents/2018-12/IDB In Brief 1428H.pdf. 
IsDB (n.d.), Lives and Livelihoods Fund, https://www.isdb.org/partnership/lives-and-livelihoodsfund.

IsDB (n.d.), Sustainable Development Goals, https://www.IsDB.org/what-we-do/sustainabledevelopment-goals.

IsDB FinTech (n.d.), Islamic Finance Challenge, https://isdbfintech.net.

Klein, M. and T. Harford (2005), Grants or Loans? Development Finance and Incentive Effects, http://siteresources.worldbank.org/EXTFINANCIALSECTOR/Resources/2828841303327122200/287Harford Klein.pdf.

Martínez-Solimán, M. (2017), Islamic Finance: An Innovative Avenue For Financing The Sustainable Development Goals, https://www.europe.undp.org/content/geneva/en/home/ourperspective/2017/3/3/Islamic-Finance-An-Innovative-Avenue-For-Financing-The-SustainableDevelopment-Goals.html.

Masdar (2017), 800MW third phase of Mohammed bin Rashid Al Maktoum Solar Park reaches financial close.

MICAD and OECD (2015), Pilot Exercise on Broader Development Finance from the UAE, https://www.oecd.org/dac/dac-globalrelations/Pilot\%20Exercise\%20on\%20Broader\%20Devel.

Migration Observatory (2016), Migrant Remittances to and from the UK, https://migrationobservatory.ox.ac.uk/resources/briefings/migrant-remittances-to-and-fromthe-ukl.

Mohieldin, M. et al. (2011), The Role of Islamic Finance in Enhancing, http://documents.worldbank.org/curated/en/393491468321563341/pdf/WPS5920.pdf.

Nadia Abas, F. and F. Raji (2018), Factors Contributing to Inefficient Management and Maintenance of Waqf Properties: A Literature Review, https://www.researchgate.net/publication/327621814 Factors Contributing to Inefficient Ma nagement and Maintenance of Waqf Properties A Literature Review.

National Zakat Foundation (n.d.), Our History, https://www.nzf.org.uk/News/ViewArticle/4240.

OECD (2018), Global Outlook on Financing for Sustainable Development 2019: Time to Face the Challenge, OECD Publishing, Paris, https://dx.doi.org/10.1787/9789264307995-en.

OECD (2018), States of Fragility 2018, OECD Publishing, Paris, https://doi.org/10.1787/9789264302075-en.

OECD (2015), Social Impact Investment: Building the Evidence Base, OECD Publishing, Paris, https://dx.doi.org/10.1787/9789264233430-en.

OECD (forthcoming), Indonesia's perspective on TOSSD.

OECD (n.d.), OECD Creditor Reporting System, https://stats.oecd.org/Index.aspx?DataSetCode=CRS1.

Range, M. and A. Kaiser-Yücel (2016), Better Understanding the Demand for Islamic Microfinance, https://www.cgap.org/blog/better-understanding-demand-islamic-microfinance. 
Rehman, A. (2019), Islamic finance for social good, https://www.undp.org/content/undp/en/home/blog/2019/IFN ANNUAL GUIDE 2019 Islamic Social Finance.html.

RFI (2019), Responsible Finance Champions: CIMB, Case Study, http://rfifoundation.org/application/uploads/RFI CIMB CaseStudy.pdf.

SDGF (n.d.), Private Sector, https://www.sdgfund.org/private-sector.

SESRIC and ISDB (2014), "Countries, Economic and Social Research and Training Centre for Islamic", in Managing Disasters and Conflicts in OIC Countries, http://www.sesric.org/files/article/486.pdf.

Shahbaz Mirza, D. (2017), From charity to perpetuity: Developing the awqaf industry in the UK, https://www.salaamgateway.com/story/from-charity-to-perpetuity-developing-the-awqafindustry-in-the-uk.

Stirk, C. (2015), An Act of Fait: Humanitarian financing and Zakat, http://devinit.org/wpcontent/uploads/2015/03/ONLINE-Zakat report V9a.pdf.

The Malaysian Reserve (2019), Global sukuk issuances up 5.5\% in 2018, https://themalaysianreserve.com/2019/08/05/global-sukuk-issuances-up-5-5-in-2018/.

UI Hassan, M. (2010), Islamic Approach of Economics: Some Discourses on Khurshid Ahmad's Vision of Socio-Economic Order, Self-Reliance and Economic Development.

UN (2019), Financing for Sustainable Development Report 2019, https://developmentfinance.un.org/fsdr2019.

UN (2019), UN Secretary General's Strategy for Financing the 2030 Agenda for Sustainable Development (2018-2021), https://www.un.org/sustainabledevelopment/sg-finance-strategy/.

UNDP (2019), Working with Islamic Finance to achieve the SDGs: A win-win?, https://www.eurasia.undp.org/content/rbec/en/home/blog/2019/islamic-finance-to-achieve-thesdgs.html.

UNDP (2018), Financing the 2030 Agenda: An Introductory Guidebook for UNDP Country Offices, http://• UNDP (2018), Financing the 2030 Agenda: An Introductory Guidebook for UNDP Country Offices, https://www.undp.org/content/dam/undp/library/Sustainable\%20Development/2030\%20Agend a/Financing the 2030 Agenda CO Guidebook.pdf.

UNDP (2016), Al Baraka pledges \$635 million towards achieving UN Sustainable Development Goals as part of its Social Responsibility Strategy, http://www.bh.undp.org/content/bahrain/en/home/presscenter/articles/2016/05/19/al-barakapledges-635-million-towards-achieving-un-sustainable-development-goals-as-part-of-itssocial-responsibility-strategy-.html.

UNDP (n.d.), Palestinian Families Economic Empowerment Programme (DEEP), http://www.ps.undp.org/content/papp/en/home/projects/deep.html.

UNDP Indonesia (2017), Indonesia shows the World how Zakaka and Waqaf can support SDGs, https://undpindonesia.exposure.co/indonesia-shows-the-world-how-zakat-and-waqaf-cansupport-sdgs. 
UNEP (2019), Al Baraka Banking Group B.S.C becomes first bank in West Asia to commit to UN Principles for Responsible Banking, http://dx.doi.org/www.unenvironment.org/news-andstories/press-release/ai-baraka-banking-group-bsc-becomes-first-bank-west-asia-commit-u.

UNHCR (2019), 2019 Mid-Year Report, https://zakat.unhcr.org/wpcontent/uploads/2019/08/UNHCRs-Refugee-Zakat-Fund-Mid-Year-Report-2019-FINALv1.pdf.

UNHCR (2019), UNHCR unveils the Refugee Zakat Fund, a global Islamic finance structure to help displaced populations worldwide, https://www.unhcr.org/hk/21715-unhcr-unveils-therefugee-zakat-fund-a-global-islamic-finance-structure-to-help-displaced-populationsworldwide.html.

UNHCR (2019), UNHCR Zakat Program: 2019 Launch Report, https://zakat.unhcr.org/hk/wpcontent/uploads/2019/04/UNHCR-Annual-Zakat-Report-2019-En.pdf.

UNHCR (n.d.), Syria emergency, https://www.unhcr.org/syria-emergency.html.

UNICEF (2019), slamic Development Bank and UNICEF to establish a Global Muslim Philanthropy Fund for Children, https://www.unicef.org/press-releases/islamic-developmentbank-and-unicef-establish-global-muslim-philanthropy-fund.

UNSDG (2018), Unlocking SDG Financing: Findings from Early Adopters, https://unsdg.un.org/resources/unlocking-sdg-financing-findings-early-adopters.

Vizcaino, R. (2013), Dubai seeks global support for Islamic endowment reforms, https://www.reuters.com/article/islamic-endowments-dubai-idUSL5N0J527X20131121.

Vodafone (n.d.), What is M-Pesa?, https://www.vodafone.com/content/index/what/m-pesa.html.

Wahid, H. (2014), Localization of Malaysian Zakat Distribution: perceptions of Amils and Zakat recipienets, https://www.researchgate.net/publication/304273549 LOCALIZATION OF MALAYSIAN ZA KAT DISTRIBUTION PERCEPTIONS OF AMILS AND ZAKAT RECIPIENTS.

World Bank (n.d.), Financial Inclusion Data / Global Findex / Sudan, http://datatopics.worldbank.org/financialinclusion/country/sudan.

World Bank (n.d.), Financial Inclusion Data / Global Findex, Islamic Republic of Iran, http://datatopics.worldbank.org/financialinclusion/country/iran,-islamic-rep.

World Bank Data (n.d.), Poverty headcount ratio, https://data. worldbank.org/indicator/SI.POV.DDAY?end=2018\&start=1960.

World Bank and Islamic Development Bank Group (2017), Global Report on Islamic Finance: Islamic Finance - A Catalyst for Shared Prosperity?

WorldData (n.d.), Organization of Islamic Cooperation, https://www.worlddata.info/alliances/oicorganization-of-islamic-cooperation.php.

Zakat (n.d.), Zakat, http://dx.doi.org/www.zakat.com.my. 